\title{
IN THE EYE OF THE BEHOLDER: TORT LITIGANTS' EVALUATIONS OF THEIR EXPERIENCES IN THE CIVIL JUSTICE SYSTEM
}

\author{
E. ALLAN LIND \\ ROBERT J. MACCOUN \\ PATRICIA A. EBENER . \\ WILLIAM L. F. FELSTINER \\ DEBORAH R. HENSLER \\ JUDITH RESNIK \\ TOM R. TYLER
}

\begin{abstract}
Little is known about the reactions of tort litigants to traditional and alternative litigation procedures. To explore this issue, we interviewed litigants in personal injury cases in three state courts whose cases had been resolved by trial, court-annexed arbitration, judicial settlement conferences, or bilateral settlement. The litigants viewed the trial and arbitration procedures as fairer than bilateral settlement, apparently because they believed that trials and arbitration hearings gave their case more respectful treatment. They were less satisfied with the outcome of judicial settlement conferences than with the outcome of bilateral settlements, because judicial settlement conference outcomes were more likely to fall below their expectations. In general, procedural justice judgments and outcome satisfaction were little related to objective outcome, cost, or delay; instead the evaluations appeared to be determined largely by perceptions of whether the procedure met litigants' criteria for procedural fairness and expectations on outcomes and costs. Gender, income, and race did not have much effect on evaluations.
\end{abstract}

\section{INTRODUCTION}

Sociolegal researchers have studied disputants' reactions to a variety of legal procedures: small-claims mediation and adjudication (McEwen and Maiman, 1981, 1982, 1984, 1986; O'Barr and Con-

The research reported here was supported in part by a grant from the $\mathrm{Na}$ tional Science Foundation Law and Social Sciences Program. The authors are grateful to Craig McEwen and Carrie Menkel-Meadow for their comments on an earlier report of this research and to Gina Ke for her comments on this manuscript. The project on which this report is based was designed and conducted by Ebener, Felstiner, Hensler, and Resnik. Lind, MacCoun, and Tyler analyzed the data. Lind, MacCoun, and Hensler wrote the report, with assistance from the other authors.

LAW \& SOCIETY REVIEW, Volume 24, Number 4 (1990) 
ley, 1985, 1988; Sarat, 1976; Vidmar, 1984, 1985, 1986); plea bargaining and criminal trial procedures (Casper, 1978; Casper et al., 1988; Heinz and Kerstetter, 1979; Houlden, 1981; Landis and Goodstein, 1986; Tyler, 1984; Tyler et al., 1989); as well as less formal encounters with police and other legal authorities (Tyler, 1988, 1990). In family law, studies have compared disputants' reactions to bilateral settlement, mediation, and adjudication (Erlanger et al., 1987; Pearson and Thoennes, 1984, 1985). However, few studies have examined how disputants involved in tort litigation react to trial procedures and to the various alternative procedures that civil courts now use to dispose of tort cases (some exceptions are Lind, 1990, and MacCoun et al., 1988). The study described here examined the attitudes and impressions of litigants in personal injury tort cases in three state courts.

In this study we considered two general questions of importance to our understanding of how litigants interpret their experiences with the legal system. First, we investigated whether outcome-related factors (such as the amount of the settlement or verdict, the cost of the litigation, and the time taken to resolve the case) have greater impact on litigants' evaluations of litigation experiences than do process-related factors (e.g., the litigant's perception that the procedure gives them control, allows participation, or treats them with respect) or litigant characteristics (e.g., litigants' race or gender). And second, we tested whether, as is often supposed, bilateral settlement is viewed more favorably than are third-party procedures. To answer these questions we interviewed tort litigants whose cases had been resolved by trial, court-annexed arbitration (a procedure in which a lawyer-arbitrator hears the case and offers a nonbinding judgment for liability and damages), settlement conference (a procedure in which a judge attempts to assist the attorneys in settling the case), and bilateral settlement. We collected data on case outcomes, litigation costs, time to case termination, and litigants' personal characteristics, and we asked the litigants about their impressions of the litigation process, the case outcome, and the cost and delay involved in resolving the case.

Our study focused on two dimensions of the litigants' evaluations of their experiences with the court: their judgments of the fairness of procedures and their satisfaction with the outcome of their case. Disputants' reactions to various dispute processing procedures have long been a topic of concern in the study of law and society (e.g., Abel, 1974; Felstiner, 1974; Gluckman, 1969; Gulliver, 1979; Nader, 1969; Nader and Todd, 1978), but until the mid-1970s, disputants' evaluations were thought of in general, undifferentiated terms. Over the past decade and a half, however, researchers have begun to distinguish between disputants' satisfaction with outcomes and their judgments of the fairness of procedures. The distinction between judgments of procedural fairness and satisfac- 
tion with outcomes arose in large part from the work of Thibaut and Walker $(1975,1978)$, which showed in laboratory settings that a procedure can be judged fair even when it yields unsatisfactory outcomes. Recent field research (e.g., Casper et al., 1988; Landis and Goodstein, 1986; MacCoun et al., 1988) has supported this distinction by demonstrating that while outcome satisfaction and procedural fairness judgments are generally correlated, the two dimensions can be distinguished empirically in the evaluations of criminal defendants and tort litigants.

\section{CASE OUTCOMES, PROCESS CONCERNS, AND LITIGANT EVALUATIONS OF LITIGATION EXPERIENCES}

\section{A. Objective Outcomes, Costs, and Delay in Litigation}

It is widely assumed that the outcome of a case-the amount won or lost-is one of the most important, if not the most important, factor affecting litigants' satisfaction and perceptions of justice. The assumption is so pervasive that it is seldom stated explicitly, but whether acknowledged or not, it underlies most policy debates and many theoretical analyses of how litigants react to justice system experiences. Economic analyses of procedures generally view litigants as concerned primarily with recoveries and payouts and with how much it costs and how long it takes to resolve the case. In policy debates, it is widely assumed that litigants' evaluations of courts and procedures are strongly influenced by whether the litigant wins or loses the case. Policymakers often assume that the only things that matter to litigants, beyond whether they win or lose, are their litigation costs and the delay they encounter in obtaining a judgment. Indeed cost and delay are often viewed as the major reasons for litigant discontent with the civil justice system (e.g., Burger, 1982; Connolly and Smith, 1983; Palmore, 1981).

Some data are available from research in other contexts, however, that raise questions about the accuracy of these assumptions. Studies of defendant reactions to criminal justice system procedures (Casper et al., 1988; Landis and Goodstein, 1986; Tyler, 1984) and of citizen reactions to encounters with police (Tyler, 1989; Tyler and Folger, 1980) have examined the extent to which the objective outcome of the case-the sentence or fine imposed-drives procedural justice judgments and outcome satisfaction. These studies have yielded inconsistent findings on the relationship between the objective outcome of the case and procedural justice judgments: some studies show at least moderate correlations between outcomes and perceived fairness, while others show no such correlation. With respect to outcome satisfaction the data are more consistent: most of the criminal justice studies have found moderate to strong correlations between satisfaction and sentence.

In tort litigation the effects of case outcome might be stronger 
for plaintiffs than for defendants, because of differences in what is at stake for each side of the dispute. Individual tort defendants are usually insured, and the outcome of the litigation often has little impact on defendants' immediate personal financial situation. Tort plaintiffs, on the other hand, have more at stake personally, and their reactions might therefore be more strongly affected by case outcome.

The nature or form of the outcome might also influence litigant evaluations of litigation experiences. Some commentators (e.g., Hayden and Anderson, 1979; Menkel-Meadow, 1985a) have suggested that adjudicatory judgments, which generally involve explicit findings on liability, can leave the loser feeling blamed, condemned, and humiliated, while procedures that involve compromise settlements achieved without explicit liability judgments do not engender such feelings. ${ }^{1}$ Similarly the winning disputant in a liability-finding procedure might experience a feeling of vindication. We tested this "vindication/condemnation" effect by comparing disputant reactions under adjudicatory procedures to reactions under more compromise-oriented procedures. ${ }^{2}$

Tort litigants' reactions to litigation costs and delay might be affected by the fee arrangements that characterize tort litigation. Like most defendants in personal injury tort cases, many defendants we interviewed were represented by lawyers who were paid by the defendant's insurer, and for such defendants personal litigation costs might be so small as to have little impact on their fairness judgments and satisfaction. Tort plaintiffs, on the other hand, pay their own attorney's fees. But because contingent fee arrangements mean that large fees occur only when there are large awards and because it is common in tort cases for the plaintiff to receive a net award from which the lawyer has already subtracted fees and costs, the absolute cost of the litigation might have less impact on tort plaintiffs than would be the case under other billing arrangements. Tort plaintiffs might be more concerned with the contingent fee rate than the total fee amount. Similarly, delay might also matter more to plaintiffs than to defendants, because it is the plaintiff who must wait for his or her money if the case is delayed.

The relation between cost and delay and litigant evaluations of

1 Another outcome-related issue concerns the "fit" of the settlement or judgment with litigants' particular needs and situations. Some commentators have claimed that because in compromise-oriented procedures, outcomes can be shaped to fit the needs of the disputants, such procedures are more satisfying and thus more fair for the litigants (e.g., Menkel-Meadow, 1985a). We did not measure this aspect of case outcomes, and therefore our study cannot speak directly to this hypothesis. As noted below, however, we can and do address the question of whether adjudicatory procedures lead to greater perceived fairness and satisfaction than does bilateral settlement.

2 We use "adjudicatory" to refer to procedures in which a third party issues a specific judgment on liability and damages; for our purposes the finality, appealability, and enforceability of the judgment are not relevant. 
procedures takes on special significance because procedures such as court-annexed arbitration and judicial settlement conferences are often designed and adopted with the goal of reducing cost and delay. Advocates of these procedures usually assume that if one succeeds in reducing cost and delay, a variety of other benefits, including greater litigant satisfaction, will necessarily follow (see, e.g., Burger, 1982). But if satisfaction and perceived fairness are not in reality linked to cost and delay, the procedural innovations, however effective in achieving these goals, might fail to produce improvements in perceived fairness and satisfaction.

\section{B. Subjective Evaluations of Outcomes, Costs, and Delay}

"Social exchange" and interdependence theories suggest that outcomes are not judged on an objective scale but rather are evaluated relative to personal standards or expectations (e.g., Adams, 1963, 1965; Blau, 1968; Homans, 1961; Kelley and Thibaut, 1978; Thibaut and Kelley, 1959). For example, Thibaut and Kelley contend that people feel satisfied when outcomes exceed a personal standard or "comparison level" (based on expectations and perceived just deserts) and dissatisfied when outcomes fall below that level. Because social exchange theories generally view satisfaction as a function of both the objective outcome and the individual's expectations, litigants with similar objective outcomes but different expectations would be expected to show quite different levels of satisfaction and perceived fairness. A similar line of reasoning might be applied to the satisfaction and perceived fairness effects of litigation costs and case duration. That is, what matters might not be how much the case actually costs and how long it takes, but rather whether it costs more and takes longer than seems reasonable to the litigant (see, e.g., Helson, 1964). According to this line of reasoning, outcome satisfaction and perceived procedural justice should be enhanced by procedures that entail less cost and less delay than the litigant expects.

\section{Alternative Views: Process and the Evaluation of Litigation Experiences}

A rather different view of what drives litigants' evaluations of the fairness of procedures is found in the work of procedural justice theorists (Brett, 1986; Lane, 1988; Leventhal, 1980; Lind and Tyler, 1988; Thibaut and Walker, 1978). Although the theories sometimes disagree about which specific factors are most important to the perception of procedural justice, all agree that people are remarkably sensitive to the process and procedures they experience in encounters with the law.

Several procedural justice theorists have suggested that perceived control over the case outcome and the litigation process are crucial factors in the perception of procedural fairness. Thibaut 
and Walker (1978), for example, argue that litigants view as fair those procedures that give them control over the litigation process, because high process control is seen as leading to fairer outcomes. Leventhal (1980) suggests that people respond favorably to procedures that seem likely to provide either accurate outcomes or outcomes that favor the person in question (depending on the goals the person brings to the situation), and this leads him to suggest that procedural fairness judgments depend on the individual's control over the decision itself, the quality of representation, and the carefulness of the procedure as a fact-finding process. Brett (1986) views people as wanting control over the procedure's outcome so that they can feel that they are in control of the dispute itself, and she sees outcome control as one of the critical factors in the perception of procedural fairness.

Other procedural justice theorists have pointed out additional factors that might determine whether a procedure is seen as fair. Lind and Tyler (1988: chap. 10) have suggested that the apparent fairness of a procedure depends largely on symbolic features of the procedure and the implications of these features for the social status of the person in question. Lind and Tyler focus in particular on whether a person receives dignified and respectful treatment when they encounter a procedure. They argue that "dignitary process" issues are extremely important to people because respectful and dignified treatment implies that one is a full-fledged, valued member of society. On the other hand, disrespectful or undignified treatment threatens one's status and provokes the judgment that the procedure is unfair. Lane (1988) advances a generally similar view of the role of dignity in procedural fairness judgments: he lists dignity of treatment as one of four major "procedural goods" that citizens expect from their government.

The idea that being treated with respect and dignity is critical to fair process is found also in legal theory. Legal analyses have pointed to dignity as one of the values underlying due process concerns (e.g., Mashaw, 1976, 1985; Michelman, 1973). These analyses hold that a fundamental feature of due process is that the state accord those who bring cases to the courts a dignified hearing. The Supreme Court's interpretation of the due process clauses of the Fifth and Fourteenth amendments recognizes this concern; in many instances, the Court has required that notice, an opportunity to be heard, and sometimes witness confrontation and cross-examination be accorded to individuals before or soon after decisions are made that affect their property or liberty interests. In imposing such requirements, the Court in essence relies on a political and legal tradition that uses process to express a commitment to limited state power and to the protection of individuals' autonomy and dignity.

The broader literature in law and society also suggests that process factors play an important role in judgments of procedural 
fairness and satisfaction with outcomes. Anthropological and sociological analyses of various dispute handling procedures suggest that procedures that allow disputants to craft their own resolution are more satisfying than are procedures that put the decision in the hands of a third party (e.g., Gluckman, 1969; Gulliver, 1979; Menkel-Meadow, 1985a; Nader, 1969; and Nader and Todd, 1978). ${ }^{3}$ Sociolegal work on disputing also emphasizes the importance of the lawyer as a source of litigant impressions of procedures. Sarat and Felstiner (1986), in a study of interaction between divorce lawyers and their clients, found that lawyers often took credit for positive events and blamed the court system, its procedures, and its judges for negative outcomes or slow progress. This work suggests a potential link between evaluations of counsel and perceptions of litigation procedures. If tort lawyers similarly attempt to improve their own image at the expense of litigant perceptions of procedural fairness, we would expect more positive evaluations of counsel to be accompanied by less positive evaluations of the court and its procedures.

The theory and rationale underlying the search for alternative dispute resolution (ADR) procedures (see, e.g., Alternative Dispute Resolution Working Group, 1986; Burger, 1982; Goldberg et al., 1985; Marks et al., 1984; North Carolina Bar Association Task Force, 1985; Pearson, 1984) also suggests that process factors are important in evaluations of the fairness of legal procedures. ${ }^{4}$ ADR advocates make a number of assumptions about how litigants view trial procedures and ADR procedures, and these assumptions suggest some process factors that might influence perceived fairness and satisfaction. In particular, much of the argument in favor of using ADR procedures involves remedying supposed shortcomings of trial. Trial procedures are thought to be difficult for litigants to understand, and therefore litigants are thought to view trial as an alienating, uncomfortable experience. In addition, the procedural complexity and formality of trial are thought to limit opportunities for litigant participation in the litigation process. ${ }^{5}$ It is often ar-

3 But it should be noted that litigant control is thought to be especially desirable in disputes involving ongoing relationships (Felstiner, 1974; Gluckman, 1969; Hayden and Anderson, 1979), a situation that rarely occurs in tort litigation.

4 Note that our discussion here concerning ADR advocates' assertions in policy debates is limited to debates concerning alternatives within the courts. Many in the ADR movement would argue that true alternative dispute resolution must involve the use of procedures entirely outside the traditional litigation process.

5 Other analysts would argue that if the informality suggests that the procedure does not allow for careful evaluation of the facts in the case, it might lower perceived fairness and outcome satisfaction. As noted above, two prominent theories of procedural justice (Leventhal, 1980; Thibaut and Walker, 1978) argue that the perceived accuracy of the procedure-its capacity to generate an outcome that fits the fact situation in dispute-is very important. According to these theories, if a procedure attempts to resolve the dispute without taking care to make the outcome congruent with the facts, the 
gued that a procedure such as court-annexed arbitration, which generally involves briefer, less formal hearings than do trials, will be seen as fairer and more satisfying because litigants will be more comfortable with the process, feel they can participate more, and feel they understand more of what is going on (Burger, 1982; North Carolina Bar Association Task Force, 1985).

\section{Litigant Characteristics}

A number of theoretical and policy analyses hypothesize that different types of litigants might react differently to litigation procedures and outcomes. For example, Gilligan's (1979, 1982; see also Menkel-Meadow, 1985b; Hardy, 1987; Resnik, 1988) analysis of gender differences in views of morality suggests that women might have different procedural justice standards than men: women may well react more favorably to procedures that result in compromise, while men might react more favorably to procedures that result in all-or-nothing outcomes (Gilligan, 1979: 486). In addition, some policy debates about litigants' likely reactions to ADR procedures include assertions that litigants will view ADR procedures as "second-class" justice in contrast to the full trial procedures provided to those with disputes involving larger sums. These assertions raise the possibility that disadvantaged litigants will react more negatively to ADR procedures than do advantaged litigants. With these issues in mind, we examined the relationships between a number of litigant characteristics and perceptions of procedural justice and outcome satisfaction.

\section{BILATERAL SETTLEMENT VERSUS THIRD-PARTY PROCEDURES 6}

We studied litigants' reactions to traditional civil trials and to two widely used alternative third-party procedures-court-annexed arbitration and judicial settlement conferences-comparing reactions to each third-party procedure with reactions to bilateral settlement. Bilateral settlement is by far the most frequent method of case resolution in tort cases, and until recently it has been viewed widely as the best way to resolve a lawsuit. Much of

procedure will probably be seen as unfair and the outcome will be less satisfying. This position-that informality might be seen as unfair-is congruent with the basic theme of some critiques of the widespread use of settlementpromoting reforms (e.g., Fiss, 1984, 1987; Resnik, 1982, 1987), which argue that the quality of justice may suffer from a focus on settling the case rather than matching the outcome to the facts in the case.

6 Our use of "bilateral settlement" should not be taken to mean that there was no court involvement in the settlement process. For example, we made no effort to exclude cases in which the terms of the settlement were registered in some fashion with the court, nor do we wish to contend that these settlements were not in part the result of court rules and schedules. We simply mean that the cases had not had a third-party hearing or conference on the substance of the case. 
the discussion above is relevant to arguments concerning litigant reactions to bilateral settlement versus third-party procedures and will not be repeated here. It is valuable to note, however, that a number of law and society researchers (e.g., McEwen and Maiman, 1981, 1982, 1984, 1986; Menkel-Meadow, 1985a) have suggested that settlement, whether accomplished by the parties and their counsel alone or assisted by judges or mediators, results in greater satisfaction because the litigants are more involved in the settlement process and because negotiated outcomes can be crafted to fit the litigants' needs. Judges and judicial administrators have also argued for bilateral settlement, suggesting that, relative to third-party procedures, settlement leads to lower costs and less delay, which will make the settlement popular with litigants.

Some recent empirical evidence reveals, however, that bilateral settlements are not always as satisfying as these arguments would suggest (Erlanger et al., 1987; see also Merry and Silbey, 1984). Further, procedural justice theorists (Lane, 1988; Leventhal, 1980; Lind and Tyler, 1988), who argue that litigant reactions are driven by concerns about the dignity and carefulness of procedures, might predict that third-party procedures would be seen as more dignified and therefore as fairer than settlement.

Of course, litigants might view some third-party procedures as fairer than bilateral settlement and others as less fair. The three third-party procedures we studied differ in a number of ways. Arbitration hearings and judicial settlement conferences are generally less formal and more private than are trials: rules of evidence are not followed to the extent they are in trials, and, unlike trials which are open to the public, it is very rare for anyone not involved in the case to attend settlement conferences and arbitration hearings of the sort we studied. ${ }^{7}$ Another difference is that, in contrast to arbitration hearings, trials are generally conducted by official judges and result in verdicts that are binding unless appealed. At trial, as in arbitration hearings, a third party renders a judgment about liability and damages. In contrast, judicial settlement conference agreements are negotiated compromises.

\section{PROCEDURES AND COURTS STUDIED ${ }^{8}$}

\section{A. Trial}

We interviewed litigants whose cases had been tried in Fairfax County, Virginia. Fairfax County, home to a relatively affluent population, consists for the most part of suburban communities of Washington, D.C. At the time of our study, attorneys in Fairfax

7 In fact, as noted below, in the settlement conferences we studied, even the litigants were routinely excluded.

8 We describe the procedures as they were enacted during the time when cases in the study were terminated (1983-84). For a discussion of the policy issues surrounding the use of each procedure, see Lind et al., 1989. 
could expect rapid movement to trial once they certified their clients' cases as ready for trial. Trials of personal injury suits involving modest amounts of damages were generally conducted expeditiously. No formal hearings or pretrial conferences were required prior to trial. Almost all the trial litigants we interviewed had jury trials. ${ }^{9}$

\section{B. Court-annexed Arbitration}

We interviewed litigants whose cases had been arbitrated in Bucks County, Pennsylvania, located in the outer suburban ring of Philadelphia. Arbitration is well established in Bucks County: At the time of the study about 90 percent of civil damage suits were disposed of through the arbitration program. As in most Pennsylvania counties (Adler et al., 1983) and many other jurisdictions with court-centered arbitration programs (Ebener and Betancourt, 1985; Hensler, 1986), arbitration hearings are held at the county courthouse in jury deliberation rooms. Typically only plaintiffs and defendants, their attorneys, and the arbitrators are present at the hearings. Only rarely are other witnesses called. The hearings are informal and brief (about forty-five minutes on average); each side is given an opportunity to present its case, but there is little procedural elaboration.

In Bucks County, civil cases are assigned to arbitration unless the statement of damages accompanying the complaint exceeds $\$ 20,000$. Each arbitration panel is composed of three attorneys, who must have a total of at least-and usually more than-ten years of legal experience. Arbitrators are selected by the court and receive no information about the cases prior to the hearings. The panel's decision is nonbinding; disputants may reject the decision and either settle the case or go to trial de novo. The arbitration award is rejected in about 9 percent of the cases. The party requesting trial de novo must post a $\$ 300$ bond; if that party improves his or her position by 10 percent or more, two-thirds of the bond (\$200) is refunded.

\section{Judicial Settlement Conference}

Prince Georges County, located in the Maryland portion of Washington's suburban ring, was the site of the judicial settlement conferences we studied. This county is less affluent and more racially mixed than the other two counties. ${ }^{10}$ At the time of the

9 All but four of the ninety-nine trial litigants in the final analytic sample had jury trials; the remaining four litigants reported that their cases had been tried by a judge without a jury.

10 If perceived fairness and satisfaction were strongly affected by income or race, this difference might pose some problems for the research design. In fact, as noted below, neither factor was found to be strongly correlated to fairness judgments or satisfaction. In addition, because we compared ratings of settlement conferences to ratings of settlements in the same county, which 
study the court was hard pressed to move cases to trial quickly. In Prince Georges County, all personal injury suits, regardless of monetary value, are assigned to the judicial settlement conference procedure, a program, like others around the country, instituted primarily to speed cases by reducing the trial rate. The conferences are held by "settlement judges"-generally not the same judges who preside at trial if cases go to trial.

Settlement judges view the conferences as bargaining sessions that provide an opportunity for counsel to take a hard look at the strengths and weaknesses of their cases and to get a neutral assessment of the value of the case. Conferences generally last one hour or less. Litigants are routinely excluded from the conferences: participation of individual litigants is viewed as unnecessary and possibly counterproductive. ${ }^{11}$ Lawyers are pressed to obtain authorization for settlement-up to a reasonable anticipated amountbefore the conference or to assure that they can reach their clients by phone during the conference. About 51 percent of the cases reaching settlement conferences are settled at the conference or after the conference but prior to trial.

The Prince Georges County judicial settlement conferences are similar to those in metropolitan state courts in California (e.g., San Francisco, Santa Clara, Los Angeles, San Bernardino) and in state courts in New Jersey, Pennsylvania, and New York.

\section{Bilateral Settlement}

We studied reactions to trial, court-annexed arbitration, and judicial settlement conference by conducting interviews with litigants in three different courts. Given the differences in jurisdictions, it was necessary to find some standard against which we could assess reactions to the third-party procedures. We chose the standard that is the most common alternative to all three procedures: bilateral settlement prior to trial, arbitration, or settlement conference. As we noted above, the comparison to bilateral settlement has theoretical, as well as methodological, advantages. In each county we interviewed litigants in cases that were similar to those exposed to the third-party procedure but resolved prior to exposure to the third-party procedure we studied in that county. ${ }^{12}$

had the same racial mix as the settlement conference procedure (20 percent of the bilateral settlement sample and 23 percent of the settlement conference sample in Prince Georges County were black), this difference could not have produced spurious differences involving the settlement conference procedure.

11 Only five of the fifty-three settlement conference litigants in our final analytic sample reported that they had attended the conference. Thus, the results of our study may not be applicable to settlement conferences regularly attended by litigants.

12 Because the adjudicatory procedures tended to issue all-or-nothing verdicts and the bilateral settlement procedure aimed explicitly at obtaining a compromise, one might wonder whether these differences affected the comparability of those interviewed in the Bucks and Fairfax settlement group. In particular, if settlement produced fewer plaintiffs who walked away with no 
The Appendix presents further information on the sites, the sample, and the research methods.

\section{PROCEDURE DIFFERENCES IN LITIGANT REACTIONS ${ }^{13}$}

In reporting our results, we consider first the differences that we found in evaluations and perceptions of the various procedures. We examine whether the procedures differed in the procedural justice judgments they engendered and whether they differed in terms of the litigants' satisfaction with outcomes. We then describe how litigants perceived the litigation process under the various procedures. In later sections we examine what factors appear to be most closely correlated with judgments of procedural fairness and with outcome satisfaction. We then examine which factors are most successful at explaining the procedure differences we found in perceived justice and satisfaction.

Before we describe our findings with respect to procedural differences, some caveats are in order. First, it should be noted that the within-court comparison approach we use here means that direct comparisons between the three third-party procedures are not possible using the values reported below, because such comparisons would include differences due to the court and county as well as differences in the procedure the litigant experienced. Thus, ratings of the three third-party procedures cannot be contrasted with one another; instead ratings of each procedure has meaning only in comparison with ratings of the bilateral settlement procedure in that county. 14

Further, the reader should keep in mind the possibility that resolution of the case by the third-party procedure or bilateral settlement might be caused by evaluations of the procedures rather than being the cause of the evaluation. That is, a litigant might

money at all or more defendants who paid out something than did the corresponding third-party procedures, and if "losers" in this sense were less likely to agree to be interviewed than were "winners," the design might contaminated. We could not determine prior to the interview whether a prospective litigant was a winner or a loser, so we cannot compare response rates across the various counties and procedures. We did ask about the case outcome in the interview, however, so we can determine whether there were any procedure-specific differences in the proportion of winners and losers: there were not.

13 We were primarily interested in cases terminated by the various thirdparty procedures or bilateral settlement. There were, however, a few respondents whose cases went to trial de novo after arbitration or settlement conferences (five in Bucks County and nine in Prince Georges County). In the analyses of procedural differences reported below, we excluded these respondents from the arbitration and settlement conference cells; including them in the analyses did not change the findings.

14 Of course, there are shortcomings to any solution to the problem of generating a standard against which one can assess the meaning of interviews such as those we conducted. Even if one eschews altogether an explicit comparison group of interviews, one is left with problems associated with comparing responses to researcher expectations or theoretical predictions. 
have refused settlement and gone to arbitration, settlement conference, or trial because he or she already regarded the third-party procedure as fairer. Similarly, a litigant might have settled prior to a third-party procedure because he or she viewed the third-party procedure as unfair. For a number of reasons, however, we do not think that such "self-selection" into procedures can account for any of our major findings. Self-selection of this sort would logically lead to favorable, but equal, ratings of the third-party procedures and their respective settlement procedures, because each procedure would be rated by litigants predisposed to favor that procedure. As seen below, this pattern of results was not observed. One would expect self-selection into procedures to result in across-theboard elevation of the ratings across a number of characteristics of the procedures. In fact, some rating scale means were high and some were low. Finally, the specific pattern of ratings we observed can be accounted for by existing theories without taking the selfselection process into account. We describe below some analyses which make it clear that differences in fairness and satisfaction ratings can be accounted for by differences in perceptions of dignity and evaluations of the case outcome relative to expectations, and these findings accord well with procedural justice and social exchange theories.

Note that the litigants could come to experience a third-party procedure as the result of their opponent's unwillingness to settle as well as a result of their own choices. Further, the litigants we interviewed might have chosen to go to, or to avoid, the third-party procedure not because they especially wanted to do so but because their lawyers advised them to do so. All these considerations lead us to believe that the differences we observed were caused by the experience of the various procedures and were not artifacts of the research design we used.

\section{A. Procedural Justice Judgments}

The litigants viewed trial and arbitration as fairer than bilateral settlement. ${ }^{15}$ Litigants' procedural fairness ratings for judicial settlement conferences were somewhat lower than were those for bilateral settlement, but the difference was not statistically signifi-

15 The analysis of procedure differences in perceived fairness used an overall analysis of variance with special contrasts comparing ratings by respondents who had experienced each third-party procedure with the ratings of respondents who experienced settlement procedures in the same county. The overall ANOVA also included contrasts designed to remove intercounty variation, insofar as was possible, in order to remove variation that would otherwise have contributed to the error term, and a test of variation attributable to the litigant's role as defendant or plaintiff. The role test was significant $(F(1$, $256)=6.43, p<.02$ ), because defendants rated all procedures higher than did plaintiffs. None of the effects in Table 3 showed any significant interaction with the litigant's role (all $F<1.0$ ), indicating that the effects in Table 3 apply to both roles. 
cant. Table 1 shows the mean procedural justice rating for each third-party procedure and each county's matched bilateral settlement group. Judgments of the relative fairness of the procedures did not differ depending on the litigant's gender, race, ${ }^{16}$ income, or employment status. ${ }^{17}$

Table 1. Procedural Justice and Outcome Satisfaction Ratings

\begin{tabular}{|c|c|c|c|c|c|c|}
\hline \multirow[b]{2}{*}{ Rating Scale } & \multicolumn{2}{|c|}{ Fairfax County } & \multicolumn{2}{|c|}{ Bucks County } & \multicolumn{2}{|c|}{$\begin{array}{c}\text { Prince Georges } \\
\text { County }\end{array}$} \\
\hline & Trial & $\begin{array}{c}\text { Settle- } \\
\text { ment }\end{array}$ & Arbitration & $\begin{array}{c}\text { Settle- } \\
\text { ment }\end{array}$ & $\begin{array}{l}\text { Settlement } \\
\text { Conference }\end{array}$ & $\begin{array}{c}\text { Settle- } \\
\text { ment }\end{array}$ \\
\hline \multirow{2}{*}{$\begin{array}{l}\text { Procedural } \\
\text { justice } \\
\text { index } \\
\text { Outcome } \\
\text { satisfaction } \\
\text { rating }\end{array}$} & $\begin{array}{l}2.70 \\
(F=\mathbf{5}\end{array}$ & $\begin{array}{c}2.21 \\
0<.016)\end{array}$ & $\begin{array}{l}3.01 \\
(F=4.21,1\end{array}$ & $\begin{array}{r}2.53 \\
-.041)\end{array}$ & \multicolumn{2}{|c|}{$\begin{array}{cr}2.61 & 2.94 \\
(F=2.51, p<.114)\end{array}$} \\
\hline & 2.24 & $.0)^{2.23}$ & $\begin{array}{r}2.27 \\
(F<1\end{array}$ & 2.17 & $\begin{array}{c}2.12 \\
(F=4.07,\end{array}$ & $\begin{array}{c}2.63 \\
(.045)\end{array}$ \\
\hline
\end{tabular}

NOTE: All ratings are on 4-point scales with higher numbers indicating greater perceived fairness or satisfaction. Because the reported means may include differences that are due to the county, as well as differences due to the procedure the litigant was rating, the means should be compared only within counties, not across counties.

\section{B. Outcome Satisfaction Ratings}

Only one of the procedure comparisons-that contrasting settlement conferences with bilateral settlement-showed a significant effect on outcome satisfaction. As can be seen from Table 1, the judicial settlement conference litigants were significantly less satisfied with their outcomes than were the Prince Georges County bilateral settlement litigants. ${ }^{18}$ In contrast, there were no substantial differences between the outcome satisfaction ratings for trial and arbitration and those for the corresponding bilateral settlement groups.

We tested for gender, race, ${ }^{19}$ income, and employment-status differences in outcome satisfaction ratings under the various pro-

16 Because in Bucks and Fairfax counties there were few minority respondents, we could not test whether minority respondents differed in their evaluations of the fairness of the arbitration and trial procedures relative to bilateral settlement. In Prince Georges County, where there were enough minority respondents to test for differences, we found no significant race difference in ratings of judicial settlement conferences and bilateral settlement.

17 The maximum $F$-value for interactions of procedure and these personal characteristics was 1.50 , not significant.

18 The analysis of variance for outcome satisfaction also showed a significant effect for the litigant's party role $(F(1,250)=13.16, p<.001)$, resulting, as did a similar effect on procedural justice, from higher ratings by defendants than plaintiffs. There were, however, no significant interactions between the role factor and the procedure.

19 The litigants' race did not affect the higher outcome satisfaction ratings for bilateral settlement relative to judicial settlement conferences. (Recall that Prince Georges County, the judicial settlement conference court, was the only court with enough minority litigants to test for racial differences.) 
cedures. None of these personal characteristics changed the outcome satisfaction ratings engendered by the four procedures. ${ }^{20}$

\section{Procedure and Perceptions of the Litigation Process}

To explore further how litigants viewed the procedures, we asked about their impressions of seven process-related features of the litigation experience: the litigants' control over events, their evaluation of their attorney, whether the procedure was dignified, whether the procedure was careful, whether they understood the procedure, whether they felt comfortable with the procedure, and the extent to which they felt they had participated in the process. Table 2 shows how the litigants viewed each procedure with respect to the seven process perception measures.

As one might expect, trials were seen as more dignified and more careful than bilateral settlements. Litigants in trials also reported that they understood the litigation process better and that they felt they participated more than did litigants in bilateral settlement cases. There was no indication that the litigants either felt less in control or less comfortable with trials than with bilateral settlements: neither measure showed any significant difference between the two groups.

The arbitration and judicial settlement conference procedures differ from bilateral settlement on only a few of the process perception variables. The litigants were somewhat more likely to describe the procedure as dignified under arbitration than under bilateral settlement. 21 Judicial settlement conferences were more likely to leave litigants feeling uncomfortable about the process than were bilateral settlements.

Finally, note that the means for the litigant control ratings are relatively low for all litigants, and that ratings of understanding of the procedure are relatively high for all litigants.

\section{CORRELATES OF PROCEDURAL JUSTICE}

How, in general, do the various factors we studied relate to procedural justice judgments? We examined the relationship between the litigants' fairness judgments and (1) measures of objective and subjective outcome, cost, and delay; ${ }^{22}$ (2) measures of perceptions of the litigation process (see the Appendix for the wording of the questions); and (3) characteristics of the litigant. Table 3 shows the relationship of each major variable to the procedural justice ratings.

20 The maximum $F$-value for interactions with procedure and these personal characteristics was 1.50 , not significant.

21 The test of this difference falls just short of statistical significance, but the difference is significant in the more sensitive structural equation analyses reported below.

22 The measures of objective outcome and cost are the litigant's personal pay-out or receipts from the litigation. 
Table 2. Perceptions of Procedures

\begin{tabular}{|c|c|c|c|c|c|}
\hline \multirow[b]{2}{*}{ Rating Scale } & Fairfas County & \multicolumn{2}{|c|}{ Bucks County } & \multicolumn{2}{|c|}{$\begin{array}{c}\text { Prince Georges } \\
\text { County }\end{array}$} \\
\hline & $\begin{array}{c}\text { Settle- } \\
\text { ment }\end{array}$ & Arbitration & $\begin{array}{l}\text { Settle- } \\
\text { ment }\end{array}$ & $\begin{array}{l}\text { Settlement } \\
\text { Conference }\end{array}$ & $\begin{array}{l}\text { Settle- } \\
\text { ment }\end{array}$ \\
\hline $\begin{array}{l}\text { Litigant control } \\
\text { index }\end{array}$ & $(F<1.0)$ & \multicolumn{2}{|c|}{$(F<1.0)$} & \multicolumn{2}{|c|}{$(F<1.0)$} \\
\hline $\begin{array}{l}\text { Attorney evaluation } \\
\text { index }\end{array}$ & $\begin{array}{c}2.94 \\
(F=1.17, \text { n.s. })\end{array}$ & $\begin{array}{l}2.89 \\
(F<1 .\end{array}$ & 0) 3.09 & $\begin{array}{l}2.96 \\
(F<1.0\end{array}$ & 3.08 \\
\hline $\begin{array}{l}\text { Procedure careful } \\
\text { index }\end{array}$ & $\begin{array}{lc}3.13 & 2.16 \\
(F=11.51, p<.001)\end{array}$ & $\begin{array}{l}2.48 \\
\quad(F<1 .\end{array}$ & $.0)^{2.26}$ & $\begin{array}{l}2.88 \\
(F=1.33\end{array}$ & $\begin{array}{l}3.20 \\
\text { n.s.) }\end{array}$ \\
\hline $\begin{array}{l}\text { Understood } \\
\text { procedure }\end{array}$ & $\begin{array}{ll}3.70 & 3.25 \\
(F=5.23, p<.005)\end{array}$ & $\begin{array}{l}3.42 \\
\quad(F<1 .\end{array}$ & $.0)^{3.21}$ & $\begin{array}{l}3.11 \\
\quad(F<1.0\end{array}$ & 0) 3.00 \\
\hline $\begin{array}{r}\text { Participated } \\
\text { in process }\end{array}$ & $\begin{array}{lc}2.86 & 2.10 \\
(F=9.43, p<.002)\end{array}$ & $\begin{array}{l}2.25 \\
(F<1 .\end{array}$ & $.0)^{2.00}$ & $\begin{array}{l}2.51 \\
(F<1.0\end{array}$ & 0) 2.28 \\
\hline $\begin{array}{l}\text { Procedure dignified } \\
\text { (\% affirmative) }\end{array}$ & $\begin{array}{cc}88.8 & 56.5 \\
(\text { Chi-square }= \\
44.87, p<.001)\end{array}$ & $\begin{array}{l}83.8 \\
\text { (Chi-sque } \\
3.20, p<\end{array}$ & $\begin{array}{l}66.7 \\
\text { are }= \\
(.08)\end{array}$ & $\begin{array}{l}78.9 \\
\text { (Chi-squa } \\
0.09, \mathrm{n} .\end{array}$ & $\begin{array}{l}80.6 \\
\text { s.) }\end{array}$ \\
\hline $\begin{array}{l}\text { Comfortable with } \\
\text { procedure } \\
\text { (\% affirmative) }\end{array}$ & $\begin{array}{c}49.4 \quad 43.5 \\
\text { (Chi-square }= \\
0.81, \text { n.s. })\end{array}$ & $\begin{array}{l}56.8 \\
\text { (Chi-sque } \\
0.07, \mathrm{n} .\end{array}$ & $\begin{array}{l}54.5 \\
\text { are }= \\
\text { s.) }\end{array}$ & $\begin{array}{l}50.0 \\
\text { (Chi-squa } \\
4.65, p<\end{array}$ & $\begin{array}{l}65.7 \\
\text { are }= \\
.05)\end{array}$ \\
\hline
\end{tabular}

NOTE: For indices and ratings entries are means of 4-point scales with higher numbers indicating greater perceived fairness or satisfaction. For dichotomous variables (dignified \& comfortable) entries are affirmative responses as a percentage of valid responses. Because the reported means may include differences that are due to the county, as well as differences due to the procedure the litigant was rating, the means should be compared only within counties, not across counties.

\section{A. Objective and Subjective Outcome, Cost, and Case Duration}

1. Objective Factors. Some of the more striking findings of the current study involve the absence of expected correlations involving procedural justice judgments. Especially remarkable is the finding that there was no consistent relationship between procedural justice judgments and the objective measures of case outcome, litigation cost, or case duration. ${ }^{23}$ As can be seen from Table

23 The absence of any correlation between perceived fairness and case duration might have been an artifact of our way of measuring case duration, but additional analyses show this to be unlikely. Because we did not have readily available information on the case filing date, we measured case duration as the time from the tort incident to the conclusion of the case. (We reasoned also that it would be the time from the incident, rather than the time from case filing, that would be most salient to the litigants.) If, however, a long time passed between the incident and the case's final resolution before the tort system was activated, there might be reason to expect that delay, as we have defined it, would not affect satisfaction or fairness judgments. Delay in taking the claim to the lawyer might not be blamed on the civil justice system and would not be expected to be correlated with procedural justice judgments. The data we do have on whether the litigants delayed substantially in pressing their claims suggest that litigants did not delay much at all in activating the tort system. We asked litigants represented by their own lawyer (i.e., the plaintiffs and the few uninsured defendants) how long after the incident they had hired the lawyer. Responses showed that the litigants acted quite quickly to activate the tort system, at least insofar as hiring a lawyer constitutes activating the system. The median time from the incident to hiring the lawyer was only 14 days; the mean, which is particularly sensitive to the long delays, 
Table 3. Correlates of Procedural Justice Judgments

\begin{tabular}{|c|c|c|c|c|c|c|}
\hline \multirow[b]{2}{*}{ Variable } & \multicolumn{2}{|c|}{ Fairfax County } & \multicolumn{2}{|c|}{ Bucks County } & \multicolumn{2}{|c|}{$\begin{array}{c}\text { Prince Georges } \\
\text { County }\end{array}$} \\
\hline & $r$ & Beta & $r$ & Beta & $\boldsymbol{r}$ & Beta \\
\hline \multicolumn{7}{|l|}{ Outcome-related variables } \\
\hline Case outcome & .17 & -.024 & .23 & .128 & .01 & .013 \\
\hline Own cost & .08 & $.147^{*}$ & .17 & .083 & -.06 & -.058 \\
\hline Case duration & -.03 & -.092 & -.13 & -.007 & -.12 & -.125 \\
\hline Subjective outcome & $.55^{* *}$ & $.597 * *$ & $.41 * *$ & $.415^{* *}$ & $.42^{* *}$ & $.418^{* *}$ \\
\hline Subjective cost & $-.08^{* *}$ & .007 & .06 & -.081 & -.27 & -.266 \\
\hline Subjective duration & -.17 & -.209 & -.06 & .036 & $-.25^{*}$ & $-.250^{*}$ \\
\hline Variance accounted for $\left(R^{2}\right)$ & & .373 & & .209 & & .252 \\
\hline \multicolumn{7}{|l|}{ Process perceptions } \\
\hline Litigant control & $.34^{* *}$ & $.192^{* *}$ & $.42^{* *}$ & $.325^{* *}$ & $.41^{* *}$ & $.406^{* *}$ \\
\hline Evaluation of attorney & $.36^{* *}$ & .088 & $.50 * *$ & $.332 * *$ & $.56^{* *}$ & $.564^{* *}$ \\
\hline Procedure dignified & $.54^{* *}$ & $.301 * *$ & $.54 * *$ & $.397 * *$ & $.48 * *$ & $.480 * *$ \\
\hline Procedure careful & $.48^{* *}$ & .175 & $.48 * *$ & .151 & $.49 * *$ & $.486 * *$ \\
\hline Understood procedure & .10 & .051 & .17 & -.080 & $.21^{* *}$ & .209 \\
\hline Comfortable with procedure & $.44^{* *}$ & .121 & $.25^{*}$ & $.296^{* *}$ & $.50^{* *}$ & $.497^{* *}$ \\
\hline Participated in process & .10 & -.151 & .21 & -.018 & .08 & .080 \\
\hline Variance accounted for $\left(R^{2}\right)$ & & .389 & & .498 & & .503 \\
\hline \multicolumn{7}{|l|}{ Litigant characteristics } \\
\hline Education & $.18^{*}$ & .160 & .02 & -.038 & .01 & .055 \\
\hline Age & -.12 & -.128 & .08 & .186 & -.16 & $-.203^{*}$ \\
\hline Gender & $-.21^{*}$ & -.176 & .14 & .175 & .14 & $.319^{* *}$ \\
\hline Race & - & - & 一 & - & .13 & .183 \\
\hline Family income & .16 & .133 & .07 & .006 & .09 & .088 \\
\hline Employed/not employed & -.15 & .043 & -.03 & -.210 & $-.32^{*}$ & $-.477^{* *}$ \\
\hline Married/not married & .07 & .078 & .05 & .058 & .02 & .155 \\
\hline Variance accounted for $\left(R^{2}\right)$ & & .101 & & .048 & & .266 \\
\hline
\end{tabular}

NOTE: Values in the " $r$ " columns show the simple correlation between each variable and the procedural justice measure; values in the "beta" columns are the standardized regression coefficients from a regression equation predicting the procedural justice measure from the variables in the category in question.

$* p<.05$. $p<.01$.

3 , there were no significant correlations and only one significant regression coefficient involving the objective measures. ${ }^{24}$

It might be argued that the absence of any correlation between objective outcome or cost and procedural fairness judgments is the result of our focus on tort litigants. We noted above that the insurance and attorney fee arrangements customary in tort litigation might mitigate against strong effects for outcomes or costs. However, additional analyses show that the relationship of proce-

is only 91 days. In contrast, the median time from the incident to the termination of the case was 731 days, and the mean was 839 days. Thus, it appears that most of the delay occurred after litigants had taken their case to the justice system.

24 The correlations and regression coefficients reported in Tables 3 and 4 and those used in the structural equation analyses are based on biserial or bichoric correlations when one of the variables is dichotomous; otherwise they are based on normalized Pearson correlations. The one exception is the use of normalized Pearson correlations for the dichotomous measure of process dignity in analyses of the Bucks County data because one biserial correlation involving the dignity rating could not be estimated, probably because of the relatively small sample in that county. 
dural justice with measures of objective outcome and cost is weak even among those litigants one might expect to be sensitive to outcomes and costs. The data show that even for litigants who personally paid out or received substantial amounts, objective outcomes and cost are not strongly related to fairness judgments. For example, plaintiffs' procedural fairness judgments were not linked more strongly to their outcomes than were those of defendants (for plaintiffs, $r=.18$, n.s., $n=133$; for defendants, $r=.04$, n.s., $n=108$ ), nor were plaintiffs' procedural justice judgments more strongly linked to their legal costs than were those of defendants (for plaintiffs, $r=.13$, n.s., $n=110$; for defendants, $r=.01$, n.s., $n=127$ ). ${ }^{25}$ Nor were plaintiffs' procedural fairness judgments significantly related to the contingent fee rate they paid ( $r=11$, n.s., $n=116)$. Among the relatively small sample of defendants who personally paid part or all of the judgment or settlement, there was no significant correlation between the case outcome and their procedural justice judgments ( $r=.12$, n.s., $n=20$ ), nor was there among those defendants who paid at least some of their own legal costs any significant correlation between what they paid and procedural justice judgments ( $r=.19$, n.s., $n=19$ ).

For neither defendants nor plaintiffs was there any substantial correlation between case duration and procedural justice judgments (for plaintiffs, $r=-.07$, n.s., $n=123$; for defendants $r=-.08$, n.s., $n=101$ ).

We noted above that it has long been suspected that litigants' reactions to adjudicatory procedures might be affected by the simple fact of winning or losing the case, because adjudicatory procedures tend to fix blame on one party or the other. We computed the correlation between procedural justice judgments and a dichotomous code of whether the respondent's side had won or lost the case $^{26}$ and found that the correlation was stronger $(r=.27, p<.001$, $n=138$ ) for respondents who experienced the adjudicatory procedures (trial and arbitration) than for those who experienced the nonadjudicatory (settlement conference and bilateral settlement) procedures $(r=.04, \mathrm{n} . \mathrm{s} ., n=96)$. That is, the difference between the procedural justice judgments of winners and those of losers was stronger in the adjudicatory procedures than in the nonadjudi-

25 As expected from the prevalence of contingent fee arrangements, the legal costs of the plaintiffs were substantially correlated with outcomes from the case $(r=.64, p<.001, n=107)$. (Here and elsewhere, the overall correlations across all three counties are based on data that have been standardized within each county.)

26 The win-lose index was constructed by counting as having "won" any plaintiff who obtained any monetary award or settlement and any defendant whose side paid nothing. Plaintiffs who received no money and defendants who paid out anything were counted as having "lost." The index is admittedly less than perfect-some plaintiffs who receive small payments relative to the injuries they suffered may have good reason to feel they have lost and some defendants who make small payments relative to the plaintiff's injuries may feel they have won. 
catory procedures. Even in the adjudicatory procedures, however, this "vindication/condemnation" effect was not strong. Further, the finding that perceived fairness was higher in the two adjudicatory procedures than in the matched bilateral settlement groups suggests that whatever negative effect an adjudicatory decision has on losers' perceptions of the fairness of procedures, that effect was more than offset by other, more attractive, features of the adjudicatory procedures.

2. Subjective Assessments. Subjective evaluations of case outcomes did show a substantial relationship with procedural justice judgments in all three counties, but subjective evaluations of case delay and litigation costs did not show any consistent relationship to procedural justice judgments. It may seem inconsistent that subjective evaluations of outcomes are correlated with procedural justice judgments while the objective measure of outcomes is not. In reality, there is no inconsistency, because subjective evaluations of the outcome showed only a very weak correlation with actual outcomes $(r=.16, p<.05, n=234)$. Apparently much of the variation in subjective outcomes is due to variation in litigants' expectations rather than to variation in the outcomes themselves. Similarly, there was no significant correlation between subjective assessments of cost and delay and the corresponding objective measures of cost and case duration ( $r=-.01, n . s ., n=124$, for subjective and objective costs; $r=.11$, n.s., $n=222$, for subjective and objective duration).

When entered together as a group in the regression equation, the objective and subjective measures of case outcome, cost, and duration account for between 21 and 37 percent of the variation in procedural justice judgments. These variables are, by and large, worse predictors of the litigants' procedural faimess judgments than are the process perception variables, but they are better predictors than are litigant characteristics. Procedural justice judgments are linked much more strongly to subjective assessments of outcomes, cost, and delay than to objective measures-most or all of the relationship between outcome, cost, and delay variables and procedural justice judgments is due to the strong relationship between fairness judgments and subjective evaluations of the outcome.

To the extent that procedural justice judgments are linked to outcomes, then, what appears to matter most is the outcome relative to expectations, not the objective magnitude of the outcome, a finding that is generally supportive of social exchange theories. In light of the frequent assertion that litigants are unhappy with traditional procedures because of the cost and delay they entail, it is noteworthy that neither objective nor subjective measures of 
cost and delay showed much relationship with procedural justice judgments. ${ }^{27}$

\section{B. Perceptions of Litigation Process}

Perceptions of the litigation process account for much (39 to 50 percent) of the variation in procedural justice judgments, as can be seen from Table 3. Perceptions of control over the case outcome and the litigation process were consistently related to procedural justice judgments. Because psychological and anthropological analyses of the importance of control differ with respect to which type of control is more closely related to procedural justice judgments, we examined the correlation of procedural justice judgments with each control item separately. We found that both decision and process control were correlated with procedural justice and that both were correlated to about the same degree (for decision control, $r=.31, p<.001, n=280$; for process control, $r=.37, p<.001, n=280$ ). We also tested whether the correlation between procedural fairness and the control measures varied depending on whether the litigant had some previous relationship with his or her opponent, and we found-contrary to what one would expect from analyses that emphasize control in ongoing relations-that perceptions of control were as highly correlated with procedural justice in the context of stranger-to-stranger disputes $(r=.31, p<.01, n=235$, for outcome control; $r=.37, p<.01, n=235$, for process control; $r=.38$, $p<.01, n=235$, for the overall control index) as they were in disputes involving those who were previously acquainted $(r=.33, p<$ $.03, n=45$, for outcome control; $r=.39, p<.01, n=45$, for process control; $r=.40, p<.01, n=45$, for the overall control index).

As shown in Table 3, evaluations of the attorney were positively correlated with procedural justice judgments. While some of the analyses reported later offer support, in one county at least, for the idea that more favorable evaluations of one's lawyer lead to less favorable evaluations of court procedures, by and large litigants viewed court procedures more favorably when they evaluated their lawyers positively.

Perceptions of the dignity of the procedure showed a consistent and strong relationship with procedural justice judgments. Litigants were substantially more likely to view the procedure as fair when they felt the litigation process was dignified.

Procedural justice judgments were consistently correlated with the litigants' ratings of how comfortable they were with the

27 It is not, of course, that the delay and expense of litigation do not matter to litigants, only that litigants do not appear to base their evaluations of the litigation experience on delay and cost considerations. In fact, litigants may view long delays and high costs as unfortunate, but unavoidable, features of any involvement with litigation, and they may look to other, more variable, features of the litigation experience when they think about fairness and satisfaction. 
procedure. However, the regression coefficients for the comfort ratings were not significant in any of the three counties, suggesting that the correlation can be attributed to the relationship of ratings of comfort with other variables in the process perception regression equation. Feelings of comfort might be driven by other perceptions, such as feelings of control or dignity, which also correlate strongly with the procedrual justice judgments.

Perceptions of procedural care showed strong correlations with procedural justice in all three counties but did not show significant regression coefficients. The nonsignificant regression coefficients suggest that perceptions of procedural care are correlated with procedural justice by virtue of the relationship of procedural care with some other process perception variable.

To summarize, litigants' perceptions of the process-especially their perceptions of the control they exercised, their perceptions of the dignity of the process, their evaluations of their counsel, and their comfort with the process-were strongly correlated with their procedural justice judgments. The strong relationship between procedural dignity and procedural fairness judgments supports procedural justice theories that emphasize the importance of dignitary process concerns. The substantial correlations between procedural justice judgments and perceived control provide support for theories that view litigants as concerned about their control over litigation events and outcomes.

\section{Litigant Characteristics}

The litigants' personal characteristics had little effect on their procedural justice judgments. As shown in Table 3, none of the litigant characteristic variables showed a consistent correlation with the fairness ratings. Taken as a group, litigant characteristics could account for only between 5 and 27 percent of the variation in procedural justice judgments. There is not much support in these data for supposing that the litigant's education, age, gender, race, income, employment status, or marital status affects his or her fairness judgments, a finding that is congruent with a recent study of tort litigants' reactions to court-annexed arbitration (MacCoun et al., 1988: 64-66)..$^{28}$

\section{CORRELATES OF OUTCOME SATISFACTION}

Table 4 shows the correlations of each of the major variables with the litigants' ratings of their satisfaction with the outcome, as well as standardized regression weights from equations predicting outcome satisfaction from each group of variables.

28 Of course, this does not mean that blacks or women or any other group were really treated as fairly as were others-only that members of these groups did not believe that the procedures they encountered were less fair than did other groups. 
Table 4. Correlates of Outcome Satisfaction Judgments

\begin{tabular}{|c|c|c|c|c|c|c|}
\hline \multirow[b]{2}{*}{ Variable } & \multicolumn{2}{|c|}{ Fairfax County } & \multicolumn{2}{|c|}{ Bucks County } & \multicolumn{2}{|c|}{$\begin{array}{l}\text { Prince Georges } \\
\text { County }\end{array}$} \\
\hline & $r$ & Beta & $r$ & Beta & $r$ & Beta \\
\hline \multicolumn{7}{|l|}{ Outcome-related variables } \\
\hline Case outcome & $.41^{*}$ & $.115^{*}$ & $.41 * *$ & $.348^{* *}$ & -.07 & $.356^{* *}$ \\
\hline Own cost & -.10 & .039 & .15 & -.074 & $-.25^{*}$ & $-.430^{* *}$ \\
\hline Case duration & .05 & .032 & -.18 & -.030 & -.16 & $-.197^{*}$ \\
\hline Subjective outcome & $.78^{* *}$ & $.774^{* *}$ & $.66^{* *}$ & $.561^{* *}$ & $.55^{* *}$ & $.580^{* *}$ \\
\hline Subjective cost & $.20^{* *}$ & $.309^{* *}$ & .25 & .051 & -.05 & $.235^{* *}$ \\
\hline Subjective duration & .03 & -.036 & -.20 & -.119 & $-.26^{*}$ & -.089 \\
\hline Variance accounted for $\left(R^{2}\right)$ & & .706 & & .545 & & .443 \\
\hline \multicolumn{7}{|l|}{ Process perceptions } \\
\hline Litigant control & $.38 * *$ & $.348^{* *}$ & $.41^{* *}$ & $.276^{*}$ & $.43^{* *}$ & $.380^{* *}$ \\
\hline Evaluation of attorney & $.50^{* *}$ & $.345^{* *}$ & $.39 * *$ & .198 & $.54^{* *}$ & $.385^{* *}$ \\
\hline Procedure dignified & $.45^{* *}$ & $.451^{* *}$ & $.29^{*}$ & .050 & $.23^{*}$ & -.048 \\
\hline Procedure careful & $.29 * *$ & -.135 & .23 & .027 & $.38^{*}$ & .084 \\
\hline $\begin{array}{l}\text { Understood procedure } \\
\text { Comfortable with }\end{array}$ & -.10 & -.122 & .12 & -.081 & .13 & -.141 \\
\hline procedure & $.31 * *$ & -.077 & $.43^{* *}$ & .185 & $.26^{* *}$ & .100 \\
\hline $\begin{array}{l}\text { Participated in process } \\
\text { Variance accounted for }\left(R^{2}\right)\end{array}$ & .06 & $\begin{array}{l}-.340^{* *} \\
.481\end{array}$ & .12 & $\begin{array}{r}-.056 \\
.274\end{array}$ & .16 & $\begin{array}{r}-.083 \\
.386\end{array}$ \\
\hline \multicolumn{7}{|l|}{ Litigant characteristics } \\
\hline Education & .06 & .048 & .19 & -.099 & -.01 & .117 \\
\hline Age & -.16 & -.116 & -.04 & .119 & $-.23^{*}$ & $-.297^{*}$ \\
\hline Gender & $-.20^{*}$ & -.196 & .23 & .226 & $.27^{*}$ & $.367^{*}$ \\
\hline Race & - & - & - & - & .03 & .052 \\
\hline Family income & .05 & .065 & .11 & .026 & -.14 & -.114 \\
\hline Employed/not employed & -.15 & .044 & -.12 & -.269 & -.03 & -.174 \\
\hline Married/not married & .15 & .138 & $.28^{*}$ & $.277^{*}$ & .08 & -.075 \\
\hline Variance accounted for $\left(R^{2}\right)$ & & .078 & & .178 & & .182 \\
\hline
\end{tabular}

NOTE: Values in the " $r$ " columns show the simple correlation between each variable and the outcome satisfaction rating; values in the "beta" columns are the standardized regression coefficients from a regression equation predicting the outcome satisfaction rating from the variables in the category in question.

$* p<.05$. * $p<.01$.

\section{A. Objective and Subjective Outcome, Cost, and Case Duration}

Outcome satisfaction correlated most strongly with the measure of subjective outcomes, that is, with ratings of where the outcome fell relative to expectations. We found smaller and less consistently significant correlations between outcome satisfaction and the objective outcome of the case and between satisfaction and both subjective and objective evaluations of litigation costs. The measures of case duration, whether objective or subjective, showed little relation to outcome satisfaction. Taken together, subjective and objective measures of outcome and related variables account for a large proportion of the variation in outcome satisfaction (44-71 percent), but the pattern of correlations and regression weights makes it clear that it is the subjective evaluation of outcomes, not the objective outcome, that matters most for satisfaction. As we noted above, subjective evaluations of outcomes showed little correlation with actual outcomes. 
1. Objective Factors. We examined the relationship between outcome satisfaction and objective outcomes, costs, and case duration within subgroups of litigants that might be especially sensitive to these factors. Plaintiff' outcome satisfaction ratings were no more highly correlated with their objective outcomes than were those of defendants $(r=.29, p<.001, n=132$, for plaintiffs; $r=.25$, $p<.01, n=107$, for defendants). Nor were plaintiffs' objective litigation costs correlated more strongly with their outcome satisfaction than those of defendants $(r=-.03$, n.s., $n=108$, for plaintiffs; $r=.13$, n.s., $n=122$, for defendants). Plaintiffs' outcome satisfaction ratings showed no relationship to the contingent fee rate they paid ( $r=-.01$, n.s., $n=115$ ). Defendants who paid their own legal costs showed no significant correlation between those costs and their outcome satisfaction ( $r=.05$, n.s., $n=19$ ), nor did defendants who themselves paid all or part of the settlement or judgment show any significant correlation between the objective outcome and their satisfaction with it ( $r=.14$, n.s., $n=20)$.

As was the case with procedural justice judgments, the outcome satisfaction ratings provided no support for the notion that defendants react negatively and plaintiffs positively to rapid resolution of the case: there was no significant correlation between outcome satisfaction and case duration for either group of litigants ( $r=-.08$, n.s., $n=122$, for plaintiffs; $r=-.03$, n.s., $n=98$, for defendants).

The outcome satisfaction judgments showed a "vindication/ condemnation" effect similar to that seen in the analyses of procedural fairness judgments. The outcome satisfaction ratings of litigants who experienced adjudicatory procedures were more highly correlated with simply winning or losing the case than were the satisfaction ratings of litigants who experienced nonadjudicatory procedures (for adjudicatory procedures, $r=.45, p<.001, n=136$; for nonadjudicatory procedures, $r=.13$, n.s., $n=96$ ). The "vindication/condemnation" effect on outcome satisfaction was somewhat stronger than that observed on procedural fairness judgments.

2. Subjective Assessments. Where the outcome falls relative to expectations appears to be the most important factor in outcome satisfaction. The low correlation between actual outcomes and outcome evaluations relative to expectations (reported above) suggests that much of the variation in subjective evaluations of outcomes, and hence much of the variation in outcome satisfaction, comes from differences in litigants' expectations about the outcome.

These findings favor more subjective models of satisfaction over those positing direct links between objective outcomes and litigant satisfaction. For this reason, social exchange theories, which emphasize evaluations of outcomes relative to expectations, fit the data better than do theories that hold that it is the objective out- 
come, cost, or duration of a case that determines whether litigants are satisfied.

\section{B. Perceptions of Litigation Process}

Process perceptions were correlated with outcome satisfaction less strongly than were the outcome-related variables but more strongly than were litigant characteristics: process perceptions could account for $27-48$ percent of the variation in outcome satisfaction.

Among the process perception variables, those suggested by control-oriented analyses of legal attitudes were most closely and most consistently related to outcome satisfaction. Perceptions of litigant control over the process and outcome showed substantial correlations with outcome satisfaction. Examination of the two scales that make up the overall litigant control index showed that both control over the process and control over the decision were correlated with outcome satisfaction (for process control, $r=.31$, $p<.001, n=273$; for decision control, $r=.41, p<.001, n=273$ ). Evaluations of one's attorney also showed substantial correlations with satisfaction with the outcome.

Perceptions of the dignity of the procedure and of procedural care and feelings of comfort with the procedure also showed significant correlations with outcome satisfaction. For these three perceptual dimensions, however, the regression coefficients were generally not significant, suggesting that the relationships revealed by the correlations were due to other factors, probably perceptions of control, which were related both to these process perceptions and to outcome satisfaction.

\section{Litigant Characteristics}

As was the case with judgments of procedural fairness, outcome satisfaction ratings showed little or no consistent correlation with any of the litigant characteristics we studied. There was no consistent correlation between outcome satisfaction and the education, age, gender, race, income, employment status, or marital status of the respondent.

\section{MODELS OF PERCEIVED FAIRNESS AND SATISFACTION}

We used structural equation analyses (Jöreskog and Sörbom, 1988) to examine which variables could explain the procedural fairness advantage of trials and arbitration hearings over bilateral settlements and the outcome satisfaction advantage of bilateral settlements over settlement conferences. We first computed structural equation models for each county with procedure and party as exogenous variables and with procedural justice (for Fairfax and Bucks counties) or outcome satisfaction (for Prince Georges 
County) as the final endogenous variable. ${ }^{29}$ The models included as intermediate (explanatory) variables any of the objective and subjective outcome, cost, and delay measures or process perception variables that showed significant correlations and significant regression weights for the fairness or satisfaction variable, depending on which effect the model was attempting to explain. ${ }^{30}$ In estimating the initial models, we assumed that the intermediate variables explained all of the procedure-based variation in fairness or satisfaction; no direct link was specified between the procedure and fairness or satisfaction. We estimated the model parameters using a maximum likelihood technique. Next, we redefined the models excluding all intermediate variables that showed no substantial causal links $(t<1.5)$ with the fairness or satisfaction variable. ${ }^{31} \mathrm{Fi}$ nally, we reestimated these second-round models, allowing a direct link between the procedure variable and fairness or satisfaction, in order to test whether the intermediate variables did indeed explain all of the procedure-based variation in fairness or satisfaction. 32

Figure 1, $A-C$, shows the results of these analyses. The values given are standardized path coefficients, which provide an index of the strength of each link in the causal chain; the arrows represent statistically significant paths. ${ }^{33}$ If a variable explains the procedure-based differences in fairness or satisfaction, it should show significant paths linking it to both the procedure and to fairness or satisfaction: that is, both paths involving the variable should be significant. In addition, if the variables in a particular model explain all of the procedure-based variation in fairness or satisfaction, the

29 The procedural justice variable was the two-scale index; the outcome satisfaction variable was the single rating scale on satisfaction with the final outcome. For multiple-scale variables the structural equation analyses took into account the scale reliability computed within the county in question; for single-scale variables an arbitrary reliability of .80 was used.

30 The term of art for such variables in psychology is "mediator" variables. Note that these tests of models assume that the variables are ordered causally with the procedural difference causing changes in the intermediate variables and these variables causing changes in the litigant evaluation variables; the present study cannot prove that ordering. In other words, we can test whether a variable is an empirically reasonable explanation of the procedure differences if the variables are ordered as assumed in the model. But in a study of this sort we cannot test definitively the ordering itself. That would require a randomized experimental design or a series of observations over time.

31 There was one deviation from this elimination process. In the model for the Bucks County data, the second-round model as originally estimated included comfort with procedure. However, this model did not fit the data. Exclusion of comfort with procedure resulted in a very good level of fit and explained the direct effect of arbitration versus settlement, so it is this latter model that is reported in Fig. $1, B$.

32 We also tested whether the intermediate variables in the final models showed significant correlations with the fairness or satisfaction measure within each procedure condition in question. In every instance these withincondition correlations were also significant.

33 Nonsignificant paths are not included in the figures. 


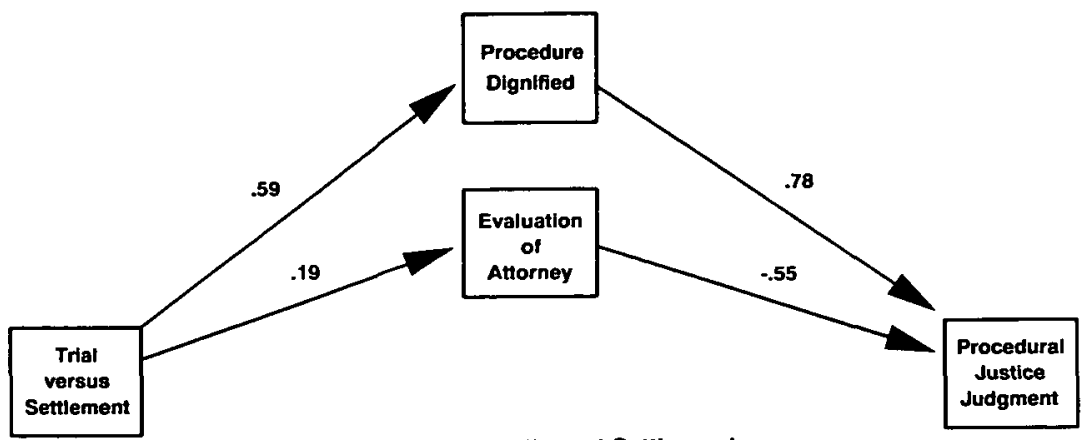

A. Trials vs. Bllateral Settlement

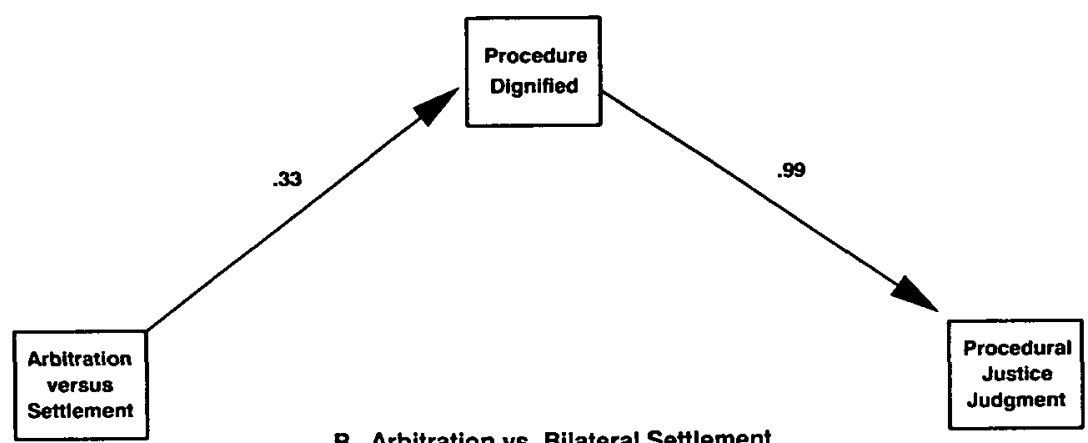

B. Arbitration vs. Bilateral Settlement

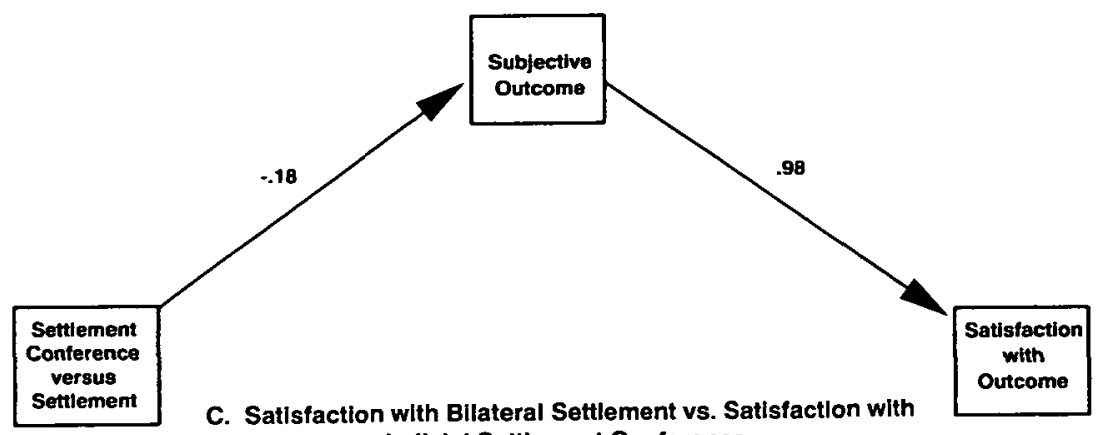
Judicial Settlement Conference

Figure 1. Causal model for the advantage $(A)$ in procedural fairness of trial over bilateral settlement, $(B)$ in procedural fairness of arbitration over bilateral settlement, and $(C)$ in satisfaction of bilateral settlement over judicial settlement conferences.

path leading directly from the procedure contrast to fairness or satisfaction should be nonsignificant and the path coefficient for that path should approach zero.

Consider first the model that seeks to explain the higher procedural fairness ratings for trials than bilateral settlements in Fairfax County. The model that produced the trial effect values in Figure $1, A$, showed a very good level of fit with the data. ${ }^{34}$ Two

34 Chi-square $(2)=.01, p>.90$, the goodness of fit index (GFI) for this model $=.99$, the adjusted goodness of fit index (AGFI) $=.99$; for the model ex- 
intermediate variables_evaluations of the attorney and dignity of the procedure-are good explanations of the procedural justice effects of trial. The role of dignity is straightforward: trials are seen as more dignified than bilateral settlements, and this greater dignity produces higher procedural justice ratings, a finding that supports theories and research that emphasize the importance of dignitary process concerns for the perception of procedural justice (Lane, 1988; Lind and Tyler, 1988; Tyler, 1988, 1989, 1990). The effects of evaluations of the attorney are more complicated. Attorneys were evaluated more positively when the case was tried, ${ }^{35}$ but these higher evaluations lead to lower procedural justice judgments. The negative causal link between evaluation of the attorney and procedural justice judgments is congruent with recent research by Sarat and Felstiner (1986), who suggest that lawyers warn their clients about the dangers of all formal process, but particularly trials, as they attempt to enhance their clients' impressions of the quality of their own services. The paths linking trials, evaluations of the attorney, and procedural justice judgments would have resulted in lower fairness ratings for trials than for bilateral settlement, absent the effect of perceived dignity. Because the positive effect of trials on feelings of dignity was so strong, however, it more than compensated for the negative attorney evaluation effect. 36

The structural equation model for the arbitration effect is simple: The procedural fairness advantage of arbitration over bilateral settlement is explained by perceptions of the dignity of the process. The arbitration-settlement structural equation model shown in Figure 1, $B$, showed very good fit with the data. ${ }^{37}$ Arbitration hearings were seen as more dignified than bilateral settlement, and perceptions of procedural dignity in turn had a substantial effect on fairness judgments. ${ }^{38}$ These findings, together with those for the trial-versus-settlement contrast, are very favorable to theories

cluding the direct link between the trial-settlement contrast and procedural fairness judgments, chi-square $(3)=.04, p>.90, \mathrm{GFI}=.99, \mathrm{AGFI}=.99$.

35 That this effect appears in these analyses but not in the analyses of variance test of procedural differences may be due to the greater sensitivity of tests in structural equations analyses, or it may be that the effect is evident only when the analysis controls for the variance in procedural justice that is explained by perceptions of procedural dignity.

36 The final causal model showed no significant direct path between the trial versus bilateral settlement contrast and procedural justice judgments, showing that perceived dignity and attorney evaluations can account for all of the procedural justice advantage of trials.

37 Chi-square (2) $=.01, p>.90$, GFI $=.99$; AGFI $=.99$; for the model excluding the direct link between the arbitration-settlement contrast and procedural fairness judgments, chi-square $(3)=.04, p>.90, \mathrm{GFI}=.99, \mathrm{AGFI}=.99$.

38 The nonsignificant direct link between the arbitration-settlement contrast and procedural fairness judgments shows that perceptions of procedural dignity are sufficient to explain the arbitration effect. 
that argue that dignitary process concerns are an important aspect of procedural justice.

The model for the adverse effect of settlement conferences on outcome satisfaction (Fig. 1,C)-shows that subjective outcome differences are the best explanation of the effect. As was the case with the two preceding models, the settlement conference model showed good fit with the data. ${ }^{39}$ There was a significant negative link between judgments of where the outcome fell relative to expectations and the settlement conference-settlement contrast, indicating that the litigants' outcomes fell below expectations more often under the settlement conference procedure than in bilateral settlement. There is also a significant positive link between subjective assessments of the outcome and satisfaction with it. ${ }^{40}$ In general, the findings from this model favor relative-outcome, "social exchange" explanations of outcome satisfaction.

\section{CONCLUSION}

Keeping in mind that our findings may be limited to the tort context, the findings described above nonetheless provide a rather remarkable picture of how tort litigants evaluate the procedures they encounter. Two findings are particularly striking. First, the litigants' views of the two adjudicatory procedures, especially their views of trials, are much more favorable than might have been expected from some common suppositions about the benefits of settlement and settlement-oriented procedures. Second, it is noteworthy that there was no substantial relationship between procedural fairness judgments and objective measures of outcome, cost, and delay. The findings with respect to the adjudicatory procedures show that some of the supposed problems of such procedures may well be exaggerated, and the findings for the objective measures show that litigant reactions depend, in the final analysis, on subjective constructions of procedures and outcomes.

\section{A. Reactions to Adjudicatory Procedures}

The litigants in Fairfax County viewed trials as dignified, careful procedures and reported that they had little trouble understanding what was happening at the trial. For them trials offered a substantial opportunity to participate in the legal process. Overall, they viewed trials as fair procedures, fairer in fact than bilateral settlement, and were as satisfied with trial outcomes as with bilat-

39 Chi-square $(2)=.01, p>.90, \mathrm{GFI}=.99, \mathrm{AGFI}=.99$; for the model excluding the direct link between the settlement conference-settlement contrast, chi-square $(3)=1.79, p>.61, \mathrm{GFI}=.99, \mathrm{AGFI}=.95$.

40 The remaining direct link between the settlement conference-bilateral settlement contrast and outcome satisfaction is not significant, but it is large enough (standardized path coefficient $=.13$ ) to suggest that the variables in the model might not explain all of the settlement conference effect on outcome satisfaction. 
eral settlement outcomes. These findings stand in sharp contrast to the conventional image of trial as an alienating, frustrating experience that leaves litigants feeling dissatisfied and unfairly treated.

Apparently, what has been overlooked in previous analyses of the likely reactions of litigants to traditional trial procedures is the considerable importance that litigants attach to being treated with respect and dignity. It has been widely assumed in both policy-oriented and academic discussions of trial procedures that the formality and ritual of trial disturb and confuse litigants. Given our findings, it seems likely that these very features of trial enhance, rather than diminish, the apparent fairness of the procedure. The structural equations analyses revealed that the perception of procedural dignity was the crucial variable leading to higher procedural fairness ratings for trials than for bilateral settlements.

But why should the perception that a procedure is dignified be so important to litigants' procedural fairness judgments? According to the Lind and Tyler group-value theory of procedural justice judgments (1988: chap. 10), the answer lies in the symbolic implications of a dignified process. Lind and Tyler suggest that dignified procedures tend to provoke favorable responses because under them litigants feel that the court accords importance to the persons and subject matter involved in the dispute. Thus, for our tort litigants, the fact the court was willing to undertake a dignified hearing of the dispute may have constituted evidence that the civil justice system took the litigants and the dispute seriously. The fact that their case was deemed important enough to receive so respectuful a hearing was probably quite flattering. After all, the trial was in all likelihood one of the most meticulous, most individualized interactions that the litigant had ever experienced in the course of his or her contacts with government agencies.

In contrast, litigants whose cases settle prior to trial may feel that their cases had not received the court's full attention and that their disputes-and thus they themselves-had not been considered important enough to warrant trial. Bilateral settlements might lack dignity in another way. Litigants may well view their case not as a dispute about outcomes but as a clash between their own view of reality and an opposing, apparently erroneous and sometimes malicious view of reality (McEwen, 1988; Merry and Silbey, 1984; Sarat and Felstiner, 1988). For such a dispute to be resolved through bilateral negotiations that focus only on money may seem to the litigants to trivialize the issues of right and wrong that are the focus of their concern.

Using procedure to express and create value is a theme that runs through legal interpretations of the due process clause of the U.S. Constitution and through commentary on how to structure adjudicatory and administrative procedures. For example, under current Supreme Court doctrine, the amount of process "due" varies with the nature of the procedural interest at stake; the stronger 
a disputant's interest, the greater the possibility that the state will be required to provide more procedural protection (Mathews $v$. Eldridge, 1976). Given this approach to the constitutional guarantees of process, our findings suggest that both the judges who developed such doctrines and the litigants in our study share the view that a procedure has the capacity both to express and to create understandings about the appropriate relations between citizen and state (Resnik, 1984). The cultural embeddedness of the litigants in our study is worth underscoring; their preferences are constructed in the context of current decisionmaking methods and the worth ascribed to them (Sunstein, 1986).

But if trials benefit from being seen as dignified, they also pose fewer disadvantages than most commentators suppose. As we note below, our data give little reason to think that litigants react positively to procedures simply because they provide a less expensive or faster means of resolving the dispute; hence, whatever cost and delay trials entail are less important to litigants than is widely assumed. Further, ADR advocates' assumptions about negative consequences of the formality of the trial process are contradicted by our findings that litigants view trials as more understandable and as offering more participation than bilateral settlements. Our findings suggest also that there is a need to reconsider how litigants view settlement processes: it may be settlement, rather than trial, that is seen as difficult to understand and that diminishes feelings of participation.

In light of the large proportion of cases that settle and the current enthusiasm for increasing settlement rates even further, there is clearly need for more extensive investigations of litigant reactions to bilateral settlement. Our findings and those of others who have looked at litigant reactions to the bilateral settlement process (Erlanger et al., 1987) raise the possibility that reforms that increase settlement rates may in fact diminish perceived justice. It is worth noting that much of the literature in praise of settlement is about how lawyers and judges view settlement. Our findings contribute to a growing literature that suggests that however popular settlement is among members of the legal community, it may be received less enthusiastically by disputants.

Trial is not the only procedure that benefits from perceptions of dignity. We found that tort litigants who experienced court-annexed arbitration procedures view arbitration as fairer than bilateral settlement, apparently because they view the arbitration hearings as more dignified than settlement negotiations. These findings give additional evidence of the role of dignity in perceptions of procedural justice and show that it is possible for procedures less formal than trial to have nonetheless sufficient dignity to lead to high levels of perceived justice.

The data do not, however, paint an unambiguously favorable picture of trial and arbitration. One hypothesized negative conse- 
quence of adjudication was borne out by our findings. The two adjudicatory procedures appeared to make litigants more sensitive to winning or losing than did the two settlement-oriented procedures. This vindication/condemnation effect supports the common supposition that adjudication leads to greater experience of blaming on the part of losers than do more conciliatory procedures. The data also point out that there is another side to the effect: Winners appear to feel better under adjudicatory procedures. We assessed the magnitude and the net result of the vindication/condemnation effect for litigant evaluations of procedures. In the present context at least, the effect on procedural fairness judgments was not as strong as previous conceptual analyses might have led one to expect. The major impact of the vindication/condemnation effect was on evaluations of the outcome, rather than on evaluations of the procedure, and the effect was not sufficiently strong to overpower the procedural fairness benefits of trial and court-annexed arbitration.

Of course, our findings with respect to procedural differences in litigant reactions apply only to tort cases; quite different evaluations may well occur in other legal contexts. As we noted above, some earlier studies in small claims and criminal court settings (Casper, 1978; McEwen and Maiman, 1984) have shown less favorable reactions to adjudication and more favorable reactions to settlement procedures. On the other hand, studies of tort and contract litigation (Lind, 1990; MacCoun et al., 1988) have produced findings that are quite consistent with those reported here, revealing relatively favorable litigant reactions to adjudication. We have no ready explanation for the apparent differences in the evaluation of adjudication and settlement procedures in different settings: there is nothing in the theoretical literature to explain the emerging pattern of findings. Clearly more research is needed to discover how procedural evaluations vary with different legal contexts.

\section{B. Subjectivity of Litigant Evaluations of Procedures and Outcomes}

The litigants' evaluations of the procedures showed little correlation with the amount they received or with the cost or delay they experienced in concluding the case, and their evaluations of the case outcome showed only moderate correlations with the objective measures of outcome, cost, and delay. In fact, objective measures of outcomes, cost, and case duration together accounted for only 3-8 percent of the variation in procedural justice judgments and for only 10-24 percent of the variation in outcome satisfaction. In contrast, subjective evaluations of the outcome, cost, and delay and subjective perceptions of the litigation process together accounted for 54-59 percent of the variation in procedural 
justice judgments and 57-82 percent of the variation in outcome satisfaction. The caveats we noted above with respect to the tort context of the study must be considered in judging the implications of these findings, but we have addressed above, and to some extent discounted, the possibility that this finding was due to the fee and outcome arrangements that characterize tort litigation.

In retrospect it may seem less than surprising that procedural justice judgments and outcome satisfaction are so subjective. After all, perceptions of procedural justice and outcome satisfaction are themselves essentially attitudinal responses, and it seems natural that they would be more closely linked to other attitudes than to objective measures of outcome, cost, or delay. There are two reasons that we nevertheless regard our findings as noteworthy. First, although in hindsight it seems reasonable that procedural justice judgments are not linked as closely to objective measures as to other attitudinal measures, it is striking that perceptions of procedural fairness are so thoroughly subjective, so completely unrelated to objective features of the litigation. Second, however reasonable the findings seem in retrospect, many policy and academic debates do assume that fairness judgments and satisfaction are closely tied to objective outcomes, cost, and delay.

To the extent that procedural justice judgments and outcome satisfaction showed links to the outcome or cost of the litigation, the crucial factor was the litigants' subjective assessment of whether the outcome or cost was more or less than expected. These subjective assessments of outcome or cost were not much related to the objective outcome or cost of the case, suggesting that most of the variation in the subjective measures of outcome and cost is attributable to differences in expectations or in standards, rather than differences in actual outcomes or costs. This, in turn, suggests that satisfaction and perceived fairness depend more on whether a litigant has modest expectations than on whether he or she actually receives favorable outcomes or low costs. The experience of justice system events such as costs or outcomes is more subjective-and more detached from objective features of the experience-than might have been expected prior to this study.

The subjective nature of procedural justice judgments and outcome satisfaction poses problems for those who attempt to improve litigant reactions by altering the economics or duration of litigation. As we noted above, those who argue for procedural innovations often assert that the reduced cost and delay they hope to achieve will produce greater litigant satisfaction and greater feelings of fairness. Our findings show that reduced cost and delay, however desirable in their own right, cannot be counted on to increase litigant satisfaction and to enhance feelings of procedural justice. Indeed, if the innovation in question somehow interferes with the enactment of a sufficiently dignified procedure, our findings suggest it will lead to dissatisfaction and perceived unfairness. 
Our findings point out the need for more research on how litigants' arrive at expectations about the likely outcome and cost of litigation. We suspect that expectations about outcome and cost are often affected by conversations with counsel, especially conversations occurring in the very early stages of litigation. There may well be other sources of outcome and cost expectations. Norms and attributions about responsibility for the incident that led to the litigation, early offers of partial payment by one's opponent (Vidmar, 1986), conventional wisdom about the expense of litigating a claim, or the comments and experiences of friends and relatives-all might affect how much litigants expect to pay and how much they expect to receive. Future studies would do well to start collecting data very early in the claiming process and to trace the origins and development of litigants' expectations.

Our study shows that litigants assess procedures in terms of how well the procedures meet their own personal standards of procedural fairness. It is clear that objective differences in procedures do affect litigants' judgments of whether their standards are met: The trial and arbitration effects we observed demonstrate that some procedures meet a standard of procedural dignity while others do not. But we need more information on how specific aspects of the litigation process affect the perceptions that drive judgments of procedural fairness (see Tyler, 1988)-more information on how objective differences in the litigation process affect subjective constructions of the process.

In addition, if we are to understand the evaluations, reactions, and decisions of litigants, we must develop a more complete picture of the procedural standards and expectations that litigants bring to the system. Our findings support theorists who emphasize the pivotal role of the construction of preferences (Sunstein, 1986) and point out the need to discover where personal procedural fairness standards come from and how some procedural characteristics come to affect procedural justice judgments while others do not. Theoretical analyses of the psychology of procedural justice suggest some basic procedural concerns, but there may well be other, as yet unknown, factors that affect whether a given procedure enhances or diminishes perceived procedural justice. We need to look at the procedural concerns and beliefs that litigants have prior to their experience with the justice system, and we need to examine how litigants' experiences with the law change, or do not change, their concerns, beliefs, and standards of fairness. Investigation of these issues has already begun (see, e.g., Merry and Silbey, 1984; O'Barr and Conley, 1988; Sarat and Felstiner, 1988; Vidmar, 1984), but more research must be done before we can understand what precisely it is that makes experiences with the civil justice system seem fair to those whom the system seeks to serve.

We must note one of the more troubling implications of our findings. Our results show that procedural justice judgments are 
heavily influenced by subjective assessments of the procedure and that outcome satisfaction depends more on expected than on objective outcomes. These findings raise the issue of false consciousness: the possibility that litigants might secure less than they deserve and be made, through manipulation of their impressions and their expectations, to like objectively unfair procedures and outcomes (Cohen; 1985, 1988). The data reported here suggest that, however regrettable, false consciousness of procedural justice might sometimes occur. Perceived justice and outcome satisfaction appear to be determined largely by subjective expectations and impressions rather than by objective features of litigation, and there is room for people to be misled.

But there are also instances, as demonstrated by these litigants' concern with procedural dignity, in which the factors that drive disputants' fairness judgments and those that figure in judicial and scholarly analyses of the meaning of procedural justice converge. We cannot assume that such convergence will always exist, however, and we should continue to examine disputants' constructions of procedural justice to discover the ways in which ordinary citizens' ideas of what constitutes justice are similar to scholarly and judicial notions of justice and the ways in which they are different.

\section{REFERENCES}

ABEL, Richard (1974) "A Comparative Theory of Dispute Institutions in Society," 8 Law \& Society Review 217.

ADAMS, J. Stacy (1965) "Inequity in Social Exchange," in L. Berkowitz (ed.), Advances in Experimental Social Psychology, Vol. 2. New York: Academic Press.

- (1963) “Toward an Understanding of Inequity," 67 Journal of Abnormal and Social Psychology 422.

ADLER, Jane W., Deborah R. HENSLER, and Charles E. NELSON (1983) Simple Justice: How Litigants Fare in the Pittsburgh Court Arbitration Program. Santa Monica, CA: RAND Corporation.

ALTERNATIVE DISPUTE RESOLUTION WORKING GROUP (1986) Dispute Resolution in Massachusetts: Final Report of the Governor's Alternative Dispute Resolution Working Group. Boston, MA: Alternative Dispute Resolution Working Group.

BLAU, Peter M. (1968) "Interaction: Social Exchange," in David L. Sills (ed.), International Encyclopedia of the Social Sciences, Vol. 7. New York: Macmillan.

BRETT, Jeanne (1986) "Commentary on Procedural Justice Papers," in R. Lewicki, B. Sheppard, and M. Bazerman (eds.), Research on Negotiation in Organizations. Greenwich, CT: JAI Press.

BURGER, Warren E. (1982) "Isn't There a Better Way?" 68 American Bar Association Journal 274.

CASPER, Jonathan D. (1978) "Having Their Day in Court: Defendant Evaluations of the Fairness of Their Treatment," 12 Law \& Society Review 237.

CASPER, Jonathan D., Tom R. TYLER, and Bonnie FISHER (1988) "Procedural Justice in Felony Cases," 22 Law \& Saciety Review 483.

COHEN, Ronald L. (1988) "Fabrications of Justice." Presented at the International Conference on Social Justice and Societal Problems, Leiden, The Netherlands, August. 
(1985) "Procedural Justice and Participation," 38 Human Relations 643.

CONNOLLY, Paul R. J., and Saundra SMITH (1983). "The Litigant's Perspective on Delay: Waiting for the Dough," 8 Justice System Journal 271.

EBENER, Patricia A., and Donna R. BETANCOURT (1985) Court-annexed Arbitration: The National Picture. Santa Monica, CA: RAND Corporation.

ERLANGER, Howard S., Elizabeth CHAMBLISS, and Marygold S. MELLI (1987) "Participation and Flexibility in Informal Processes: Cautions from the Divorce Context," 21 Law \& Society Review 585.

FELSTINER, William L. F. (1974) "Influences of Social Organization on Dispute Processing," 9 Law \& Society Review 63.

FISS, Owen M. (1987) "Justice Chicago Style," 1987 University of Chicago Legal Forum 1. (1984) “Against Settlement," 93 Yale Law Journal 1073.

GILLIGAN, Carol (1982) In a Different Voice: Psychological Theory and Women's Development. Cambridge, MA: Harvard University Press.

- (1979) "In a Different Voice: Women's Conceptions of Self and of Morality," 47 Harvard Educational Review 481.

GLUCKMAN, Max (1969) Ideas and Procedures in African Customary Law. London: Oxford University Press.

GOLDBERG, Stephen B., Eric D. GREEN, and Frank E. A. SANDER (1985) Dispute Resolution. Boston, MA: Little, Brown \& Co.

GULLIVER, Philip H. (1979) Disputes and Negotiations: A Cross-cultural Perspective. New York: Academic Press.

HARDING, Sandra G. (1987) The Science Question in Feminism. Ithaca, NY: Cornell University Press.

HAYDEN, Robert M., and Jill K. ANDERSON (1979) "On the Evaluation of Procedural Systems in Laboratory Experiments: A Critique of Thibaut and Walker," 3 Law and Human Behavior 21.

HEINZ, Anne, and Wayne KERSTETTER (1979) "Pretrial Settlement Conference: Evaluation of a Reform in Plea Bargaining," 13 Law \& Society Review 349.

HELSON, Harry (1964) Adaptation-Level Theory. New York: Harper \& Row.

HENSLER, Deborah R. (1986) "What We Know and Don't Know About Court-administered Arbitration," 69 Judicature 270.

HOMANS, George C. (1961) Social Behaviour: Its Elementary Forms. London: Routledge \& Kegan Paul.

HOULDEN, Pauline (1981) "Impact of Procedural Modification on Evalustions of Plea Bargaining," 15 Law \& Society Review 267.

JÖRESKOG, Karl G., and Dag SÖRBOM (1988) LISREL 7: A Guide to the Program and Applications. Chicago: SPSS, Inc.

KEILEY, Harold H., and John W. THIBAUT (1978) Interpersonal Relations: $A$ Theory of Interdependence. New York: Wiley.

LANDIS, Jean M., and Lynne GOODSTEIN (1986) "When Is Justice Fair?" 1986 American Bar Foundation Research Journal 675.

LANE, Robert E. (1988) "Procedural Goods in a Democracy: How One Is Treated Versus What One Gets," 2 Social Justice Research 177.

LEVENTHAL, Gerald S. (1980) "What Should Be Done with Equity Theory? New Approaches to the Study of Fairness in Social Relationships," in $\mathbf{K}$. Gergen, M. Greenberg, and R. Willis (eds.), Social Exchange: Advances in Theory and Research. New York: Plenum Press.

LIND, E. Allan (1990) Arbitrating High-Stakes Cases: An Evaluation of Courtannexed Arbitration in a United States District Court. Santa Monica, CA: RAND Corporation.

LIND, E. Allan, Robert J. MacCOUN, Patricia A. EBENER, William L. F. FELSTINER, Deborah R. HENSLER, Judith RESNIK, and Tom R. TYLER (1989) The Perception of Justice: Tort Litigants' Views of Trials, Court-annexed Arbitration, and Judicial Settlement Conferences. Santa Monica, CA: RAND Corporation.

LIND, E. Allan, and Tom R. TYLER (1988) The Social Psychology of Procedural Justice. New York: Plenum Press.

MacCOUN, Robert J., E. Allan LIND, Deborah R. HENSLER, David L. BRYANT, and Patricia A. EBENER (1988) Alternative Adjudication: An Evaluation of the New Jersey Automobile Arbitration Program. Santa Monica, CA: RAND Corporation. 
MARKS, Jonathan B., Earl E. JOHNSON, Jr., and Peter L. SZANTON (1984) Dispute Resolution in America: Processes in Evolution. Washington, DC: National Institute for Dispute Resolution.

MASHAW, Jerry L. (1985) Due Process in the Administrative State. New Haven, CT: Yale University Press.

(1976) "The Supreme Court's Due Process Calculus for Administrative Adjudication in Mathews $v$. Eldridge: Three Factors in Search of a Theory of Value," 44 University of Chicago Law Review 28.

McEWEN, Craig A. (June, 1988) "Choosing to Settle: Lessons About Disputant Expectations for Justice." Presented at the Law and Society Association Annual Meeting, Vail, CO.

McEWEN, Craig A., and Richard J. MAIMAN (1986) "The Relative Significance of Disputing Forum and Dispute Characteristics for Outcome and Compliance," 20 Law \& Society Review 439.

(1984) "Mediation in Small Claims Court: Achieving Compliance Through Consent," 18 Law \& Society Review 11.

(1982) "Arbitration and Mediation as Alternatives to Court," 10 Policy Studies Journal 712.

Studies1) "Small Claims Mediation in Maine: An Empirical Assessment," 33 Maine Law Review 237.

MENKEL-MEADOW, Carrie (1985a) "For and Against Settlement: Uses and Abuses of the Mandatory Settlement Conference," 33 UCLA Law Review 485.

485. (1985b) "Portia in a Different Voice: Speculations on a Women's Lawyering Process," 1 Berkeley Women's Law Journal 39.

MERRY, Sally E., and Susan S. SILBEY (1984) "What Do Plaintiffs Want? Reexamining the Concept of Dispute," 9 Justice System Journal 151.

MICHELMAN, Frank I. (1973) "The Supreme Court and Litigation Access Fees: The Right to Protect One's Rights-Part I," 1973 Duke Law Journal 1153.

NADER, Laura (1969) "Styles of Court Procedure: To Make the Balance," in L. Nader (ed.), Law in Culture and Society. Chicago: Aldine.

NADER, Laura, and Harry F. TODD (1978) The Disputing Process: Law in Ten Societies. New York: Columbia University Press.

NORTH CAROLINA BAR ASSOCIATION TASK FORCE (1985) "Dispute Resolution: A Task Force Report by the North Carolina Bar Foundation." Raleigh: North Carolina Bar Association.

O'BARR, William M., and John M. CONLEY (1988) "Lay Expectations of the Civil Justice System," 22 Law \& Society Review 137.

- (1985) "Litigant Satisfaction Versus Legal Adequacy in Small Claims Court Narratives," 19 Law \& Society Review 661.

PALMORE, John S. (1981) "The Urgency of Economic Litigation," 67 American Bar Association Journal 814.

PEARSON, Jessica (1984) "An Evaluation of Alternatives to Court Adjudication," 7 Justice System Journal 420.

PEARSON, Jessica, and Nancy THOENNES (1985) "Mediation Versus the Courts in Child Custody Cases," 1 Negotiation Journal 235.

- (1984) "Mediating and Litigating Custody Disputes: A Longitudinal Evaluation," 17 Family Law Quarterly 497.

RESNIK, Judith (1988) "On the Bias: Feminist Reconsiderations of the Aspirations for Our Judges," 61 Southern California Law Review 1877. rations) "Judging Consent," 1987 University of Chicago Legal Forum 43.

- (1982) "Managerial Judges," 96 Harvard Law Review 374.

SARAT, Austin (1976) "Alternatives in Dispute Processing: Litigation in a Small Claims Court," 10 Law \& Society Review 339.

SARAT, Austin, and William L. F. FELSTINER (1988) "Law and Social Relations: Vocabularies of Motive in Lawyer/Client Interaction," 22 Law \& So-

ciety Review 737 . Society Review 94.

Society Review 94.
SUNSTEIN, Cass R. (1986) "Legal Interference with Private Preferences," 53 University of Chicago Law Review 1129. 
THIBAUT, John, and Harold H. KELLEY (1959) The Social Psychology of Groups. New York: Wiley.

THIBAUT, John, and Laurens WALKER (1978) "A Theory of Procedure," 66 California Law Review 541.

(1975) Procedural Justice: A Psychological Analysis. Hillsdale, NJ: Erlbaum.

TYLER, Tom R. (1990) Why Citizens Obey the Law: Procedural Justice, Legitimacy and Compliance. New Haven, CT: Yale University Press.

(1989) "The Quality of Dispute Resolution Procedures and Outcomes: Measurement Problems and Possibilities," 66 Denver University Law Review 419.

(1988) "What Is Procedural Justice? Criteria Used by Citizens to Assess the Fairness of Legal Procedures," 22 Law \& Society Review 301.

(1984) "The Role of Perceived Injustice in Defendants' Evaluations of Their Courtroom Experience," 18 Law \& Society Review 51.

TYLER, Tom R., Jonathan D. CASPER, and Bonnie FISHER (1989) "Maintaining Allegiance to Political Authorities: The Role of Prior Attitudes and the Use of Fair Procedures," 33 American Journal of Political Science 629.

TYLER, Tom R., and Robert FOLGER (1980) "Distributional and Procedural Aspects of Satisfaction with Citizen-Police Encounters," 1 Basic and Applied Social Psychology 281.

VIDMAR, Neil (1986) "Assessing the Effects of Case Characteristics and Settlement Forum on Dispute Outcomes and Compliance," 21 Law \& Society Review 156.

- (1985) "An Assessment of Mediation in a Small Claims Court," 41 Journal of Social Issues 127.

- (1984) "The Small Claims Court: A Reconceptualization of Disputes and an Empirical Investigation," 18 Law \& Society Review 515.

WALL, James A., Jr., and Lawrence F. SCHILLER (1983) "The Judge Off the Bench: A Mediator in Civil Settlement Negotiations," in M. H. Bazerman and R. J. Lewicki (eds.), Negotiating in Organizations. Beverly Hills, CA: Sage Publications.

\section{CASE CITED}

Mathews v. Eldridge, 424 U.S. 319 (1976). 


\section{APPENDIX}

\section{SITES, SAMPLES, AND RESEARCH METHODS}

A discussion of our criteria for selecting courts and litigants for the study can be found in Lind et al (1989). Table A1 shows the breakdown of completion rates as we moved from our initial sample of potential eligible respondents to our final analytic sample.

Table A1. Survey Completion Rates

\begin{tabular}{|c|c|c|c|c|}
\hline & $\begin{array}{l}\text { Total } \\
\text { Sample }\end{array}$ & $\begin{array}{l}\text { Bucks } \\
\text { County }\end{array}$ & $\begin{array}{l}\text { Fairfax } \\
\text { County }\end{array}$ & $\begin{array}{c}\text { Prince Georges } \\
\text { County }\end{array}$ \\
\hline Eligible telephone sample & 1,259 & 437 & 409 & 413 \\
\hline Not locatable & 410 & 115 & 143 & 152 \\
\hline Net telephone sample & 849 & 322 & 266 & 261 \\
\hline $\begin{array}{l}\text { Refused } \\
\quad \text { Percentage of net telephone }\end{array}$ & 255 & 105 & 81 & 69 \\
\hline sample & $30 \%$ & $33 \%$ & $30 \%$ & $26 \%$ \\
\hline Not reached during field period & 188 & 87 & 36 & 65 \\
\hline $\begin{array}{l}\text { Completed telephone interviews } \\
\text { Percentage of net telephone } \\
\text { sample interviewed litigants }\end{array}$ & 406 & 130 & 149 & 127 \\
\hline $\begin{array}{l}\text { excluded from final sample: } \\
\text { Property damage only } \\
\text { Case value reported to be }\end{array}$ & $\begin{array}{l}48 \% \\
58\end{array}$ & $\begin{array}{l}40 \% \\
41\end{array}$ & $\begin{array}{l}56 \% \\
14\end{array}$ & $\begin{array}{c}49 \% \\
3\end{array}$ \\
\hline greater than $\$ 35,000$ & 15 & 2 & 4 & 9 \\
\hline Unable to identify procedure & 47 & 13 & 9 & 25 \\
\hline Final analytic sample & 286 & 74 & 122 & 90 \\
\hline
\end{tabular}

\section{A. Characteristics of the Final Analytic Sample}

The average age of litigants in the final analytic sample was 40. The sample included 166 (58 percent) men and 120 (42 percent) women. Eighty-five percent of the sample were employed full or part time outside the home. Sixty-five percent were married. The sample was 88 percent Caucasian, 9 percent Black, and 3 percent other ethnic groups. Eight percent of the sample had not completed high school, 27 percent had a high-school diploma, 31 percent had some college, and the remaining 33 percent had a college degree. Five percent of the sample reported a total family income of $\$ 10,000$ or less, 16 percent reported income between $\$ 10,000$ and $20,000,19$ percent reported income between $\$ 25,000$ and $\$ 35,000,28$ percent reported income between $\$ 35,000$ and $\$ 50,000$, and 32 percent reported income over $\$ 50,000$.

The final analytic sample consisted of 145 plaintiffs and 141 defendants. Ninety-eight percent of the plaintiffs and 100 percent of the defendants were represented by counsel. Ninety percent of the defendants were insured, and most (86 percent of all defendants) were represented by lawyers supplied by their insurance company. Nearly all (94 percent) of the plaintiffs reported that their lawyers were working on a contingent fee arrangement. The 
most frequent contingent fee rate was one-third of the award: 70 percent of the contingent fee plaintiffs reported this rate. The range of reported contingent fee rates was 10 to 60 percent of the award; about 8 percent of the contingent fee plaintiffs reported rates less than one-third of the award, and about 22 percent reported rates greater than one-third of the award.

Most (78 percent) of the cases in which the respondents had been involved were automobile-related personal injury torts; the remainder were other personal injury torts. Most respondents had no relationship with their opponent prior to the incident that initiated the case: Only 16 percent reported any business or personal relationship prior to the case.

Some litigants had more at stake than did others. Plaintiffs, for example, had more at stake in terms of outcomes and costs than did defendants: The net outcome received by the plaintiffs ranged from $\$ 0$ to $\$ 35,000$ with a mean of $\$ 7,622$, and the litigation costs and legal fees paid by the plaintiffs ranged from $\$ 0$ to $\$ 18,006$ with a mean of $\$ 3,767$; in contrast, while the defendants' out-ofpocket payments for settlement and judgments ranged from $\$ 0$ to $\$ 19,000$, their mean out-of-pocket payment was only $\$ 1,536$. Defendants' out-of-pocket payment for legal costs ranged from $\$ 0$ to $\$ 5,000$, but their mean out-of-pocket cost was only $\$ 221$. It should be noted that about 14 percent of the defendants paid directly some or all of the case outcome; the amount these defendants paid ranged from $\$ 0$ to $\$ 19,000$ with a mean of $\$ 6,647$. Similarly, approximately 14 percent of defendants paid at least part of their own legal costs; their legal costs ranged from $\$ 0$ to $\$ 5,000$ with a mean of $\$ 1,591$.

\section{B. Questions Used in the Interviews}

A copy of the entire interview protocol can be obtained from the authors. The following questions were used to collect data on the subjective variables discussed in this article. (Mean values are scaled so that higher values represent ratings in the direction of the variable name. The tables that follow include all responses; data for litigants who went to trial after arbitration or settlement conference are included.)

\section{PROCEDURAL FAIRNESS}

Question 1.

[Arbitration] "At the time you went through it, how fair did you think the arbitration hearing procedure was?"

[Judicial settlement conference] "At the time the conference took place, how fair did you think it was?"

[Trial] "At the time you went through it, how fair did you think the trial was?" 
[Settlement] "At the time, how fair did you think the settlement process was?"

[For all versions] Response options: "Very fair," "Somewhat fair," "Somewhat unfair," "Very unfair." (Scale values = 1-4)

\begin{tabular}{lcccccccc}
\hline & \multicolumn{2}{c}{ Fairfax } & & \multicolumn{2}{c}{ Bucks } & & \multicolumn{2}{c}{ Prince Georges } \\
\cline { 2 - 3 } & Trial & $\begin{array}{c}\text { Settle- } \\
\text { ment }\end{array}$ & & Arbitration & $\begin{array}{c}\text { Settle- } \\
\text { ment }\end{array}$ & & $\begin{array}{c}\text { Settlement } \\
\text { Conference }\end{array}$ & $\begin{array}{c}\text { Settle- } \\
\text { ment }\end{array}$ \\
\hline Mean & 2.68 & 2.11 & & 3.14 & 2.51 & & 2.46 & 2.79 \\
S.D. & 1.13 & 1.06 & & 0.89 & 1.03 & & 1.05 & 0.83 \\
$N$ & 97 & 24 & & 51 & 22 & & 52 & 35 \\
\hline
\end{tabular}

Question 2. Finally, looking back, do you think the procedure that was used for resolving your dispute was:"

Response options: "Very fair," "Somewhat fair," "Somewhat unfair," "Very unfair." (Scale values $=1-4$ )

\begin{tabular}{|c|c|c|c|c|c|c|}
\hline & \multicolumn{2}{|c|}{ Fairfax } & \multicolumn{2}{|c|}{ Bucks } & \multicolumn{2}{|c|}{ Prince Georges } \\
\hline & Trial & $\begin{array}{c}\text { Settle- } \\
\text { ment }\end{array}$ & Arbitration & $\begin{array}{c}\text { Settle- } \\
\text { ment }\end{array}$ & $\begin{array}{l}\text { Settlement } \\
\text { Conference }\end{array}$ & $\begin{array}{c}\text { Settle- } \\
\text { ment }\end{array}$ \\
\hline Mean & 2.70 & 2.42 & 2.87 & 2.62 & 2.76 & 3.08 \\
\hline S.D. & 1.13 & 0.97 & 1.04 & 1.06 & 0.99 & 0.63 \\
\hline$N$ & 97 & 24 & 51 & 22 & 52 & 35 \\
\hline
\end{tabular}

OUTCOME SATISFACTION. "How did you feel about the final outcome-were you:

Response options: "Very satisfied," "Somewhat satisfied," "Somewhat dissatisfied," "Very dissatisified." (Scale values $=1-4$ )

\begin{tabular}{|c|c|c|c|c|c|c|}
\hline & \multicolumn{2}{|c|}{ Fairfax } & \multicolumn{2}{|c|}{ Bucks } & \multicolumn{2}{|c|}{ Prince Georges } \\
\hline & Trial & $\begin{array}{l}\text { Settle- } \\
\text { ment }\end{array}$ & Arbitration & $\begin{array}{l}\text { Settle- } \\
\text { ment }\end{array}$ & $\begin{array}{l}\text { Settlement } \\
\text { Conference }\end{array}$ & $\begin{array}{c}\text { Settle- } \\
\text { ment }\end{array}$ \\
\hline$\overline{\text { Mean }}$ & 2.24 & 2.26 & 2.30 & 2.18 & 2.25 & 2.63 \\
\hline S.D. & 1.26 & 1.21 & 1.25 & 1.00 & 1.21 & 0.94 \\
\hline$N$ & 97 & 23 & 47 & 22 & 51 & 35 \\
\hline
\end{tabular}

EVALUATION OF CASE OUTCOME. "Compared to what you expected when the case was first filed, was the final outcome:"

Response options: "Better than you expected," "worse than you expected," "Just about what you expected." (Scale values $=1-4$ )

\begin{tabular}{|c|c|c|c|c|c|c|}
\hline & \multicolumn{2}{|c|}{ Fairfax } & \multicolumn{2}{|c|}{ Bucks } & \multicolumn{2}{|c|}{ Prince Georges } \\
\hline & Trial & $\begin{array}{l}\text { Settle- } \\
\text { ment }\end{array}$ & Arbitration & $\begin{array}{l}\text { Settle- } \\
\text { ment }\end{array}$ & $\begin{array}{l}\text { Settlement } \\
\text { Conference }\end{array}$ & $\begin{array}{c}\text { Settle- } \\
\text { ment }\end{array}$ \\
\hline Mean & 2.01 & 2.04 & 1.94 & 2.07 & 2.10 & 2.45 \\
\hline S.D. & 1.21 & 1.15 & 1.06 & 0.97 & 1.19 & 1.15 \\
\hline$N$ & 94 & 23 & 48 & 21 & 52 & 33 \\
\hline
\end{tabular}


EVALUATION OF CASE DURATION. "Considering what had to be done, do you think the time it took for your case to get resolved was:

Response options: "Very reasonable," Somewhat reasonable," "Somewhat unreasonable," "Very unreasonable." (Scale values = 1-5)

\begin{tabular}{lcccccccc}
\hline & \multicolumn{2}{c}{ Fairfax } & & \multicolumn{2}{c}{ Bucks } & & \multicolumn{2}{c}{ Prince Georges } \\
\cline { 2 - 3 } & Trial & $\begin{array}{c}\text { Settle- } \\
\text { ment }\end{array}$ & & Arbitration & $\begin{array}{c}\text { Settle- } \\
\text { ment }\end{array}$ & & $\begin{array}{c}\text { Settlement } \\
\text { Conference }\end{array}$ & $\begin{array}{c}\text { Settle- } \\
\text { ment }\end{array}$ \\
\hline Mean & 3.37 & 2.91 & & 3.39 & 3.23 & & 3.75 & 2.69 \\
S.D. & 1.47 & 1.48 & & 1.50 & 1.60 & & 1.45 & 1.47 \\
$N$ & 98 & 22 & & 51 & 22 & & 53 & 35 \\
\hline
\end{tabular}

"Did it take too much time to resolve the case or was there not enough time?" [Asked if response to above was not "Very reasonable"]

Response options: "Too much time," "Not enough time."

\begin{tabular}{|c|c|c|c|c|c|c|}
\hline & \multicolumn{2}{|c|}{ Fairfax } & \multicolumn{2}{|c|}{ Bucks } & \multicolumn{2}{|c|}{ Prince Georges } \\
\hline & Trial & $\begin{array}{l}\text { Settle- } \\
\text { ment }\end{array}$ & Arbitration & $\begin{array}{l}\text { Settle- } \\
\text { ment }\end{array}$ & $\begin{array}{l}\text { Settlement } \\
\text { Conference }\end{array}$ & $\begin{array}{c}\text { Settle- } \\
\text { ment }\end{array}$ \\
\hline $\begin{array}{l}\text { Percent too } \\
\text { much time } \\
N\end{array}$ & $\begin{array}{l}87 \% \\
85\end{array}$ & $\begin{array}{l}65 \% \\
20\end{array}$ & $\begin{array}{l}91 \% \\
44\end{array}$ & $\begin{array}{l}72 \% \\
18\end{array}$ & $\begin{array}{l}88 \% \\
48\end{array}$ & $\begin{array}{l}64 \% \\
28\end{array}$ \\
\hline
\end{tabular}

EVALUATION OF LITIGATION COST. "All things considered, do you think you got your money's worth from your attorney or not?"

Response options: "Yes," "No."

\begin{tabular}{|c|c|c|c|c|c|c|}
\hline & \multicolumn{2}{|c|}{ Fairfax } & \multicolumn{2}{|c|}{ Bucks } & \multicolumn{2}{|c|}{ Prince Georges } \\
\hline & Trial & $\begin{array}{c}\text { Settle- } \\
\text { ment }\end{array}$ & Arbitration & $\begin{array}{c}\text { Settle- } \\
\text { ment }\end{array}$ & $\begin{array}{l}\text { Settlement } \\
\text { Conference }\end{array}$ & $\begin{array}{c}\text { Settle- } \\
\text { ment }\end{array}$ \\
\hline $\begin{array}{l}\text { Percent yes } \\
N\end{array}$ & $\begin{array}{l}64 \% \\
53\end{array}$ & $\begin{array}{c}56 \% \\
9\end{array}$ & $\begin{array}{l}41 \% \\
29\end{array}$ & $\begin{array}{l}50 \% \\
12\end{array}$ & $\begin{array}{l}63 \% \\
32\end{array}$ & $\begin{array}{l}47 \% \\
15\end{array}$ \\
\hline
\end{tabular}

\section{PERCEIVED CONTROL}

Outcome Control. "How much control did you feel you had over the outcome of your case?"

Response options: "A great deal," "Some," "A little," "Not much." (Scale values $=1-4$ )

\begin{tabular}{|c|c|c|c|c|c|c|}
\hline & \multicolumn{2}{|c|}{ Fairfax } & \multicolumn{2}{|c|}{ Bucks } & \multicolumn{2}{|c|}{ Prince Georges } \\
\hline & Trial & $\begin{array}{l}\text { Settle- } \\
\text { ment }\end{array}$ & Arbitration & $\begin{array}{l}\text { Settle- } \\
\text { ment }\end{array}$ & $\begin{array}{l}\text { Settlement } \\
\text { Conference }\end{array}$ & $\begin{array}{c}\text { Settle- } \\
\text { ment }\end{array}$ \\
\hline $\begin{array}{l}\text { Mean } \\
\text { S.D. } \\
N\end{array}$ & $\begin{array}{l}1.86 \\
1.09 \\
97\end{array}$ & $\begin{array}{l}1.80 \\
1.06 \\
24\end{array}$ & $\begin{array}{l}1.69 \\
0.96 \\
52\end{array}$ & $\begin{array}{l}1.90 \\
1.31 \\
22\end{array}$ & $\begin{array}{l}1.86 \\
1.12 \\
52\end{array}$ & $\begin{array}{l}2.04 \\
1.23 \\
37\end{array}$ \\
\hline
\end{tabular}


Process Control. "Overall, thinking about your dealings with the court and with your lawyer, how much control would you say you had over the way your case was handled?"

Response options: "A lot," "Some," "A little," "Not much." (Scale values $=1-4)$

\begin{tabular}{lcccccccc}
\hline & \multicolumn{2}{c}{ Fairfax } & & \multicolumn{2}{c}{ Bucks } & & \multicolumn{2}{c}{ Prince Georges } \\
\cline { 2 - 3 } & Trial & $\begin{array}{c}\text { Settle- } \\
\text { ment }\end{array}$ & & Arbitration & $\begin{array}{c}\text { Settle- } \\
\text { ment }\end{array}$ & & $\begin{array}{c}\text { Settlement } \\
\text { Conference }\end{array}$ & $\begin{array}{c}\text { Settle- } \\
\text { ment }\end{array}$ \\
\hline Mean & 2.33 & 2.13 & & 2.01 & 2.18 & & 2.11 & 2.27 \\
S.D. & 1.10 & 1.12 & & 1.06 & 1.18 & & 1.17 & 1.14 \\
$N$ & 97 & 24 & & 52 & 22 & & 52 & 37 \\
\hline
\end{tabular}

\section{EVALUATION OF COUNSEL}

Question 1. "People have different opinions and experiences with lawyers. Thinking about your lawyer and the way he/she handled the case, do you think his/her knowledge of the facts in your case was:"

Response options: "More than adequate," "Adequate," "Not adequate." (Scale values $=1-5$ )

\begin{tabular}{llccccccc}
\hline & \multicolumn{2}{c}{ Fairfax } & & \multicolumn{2}{c}{ Bucks } & & \multicolumn{2}{c}{ Prince Georges } \\
\cline { 2 - 3 } & Trial & $\begin{array}{c}\text { Settle- } \\
\text { ment }\end{array}$ & & Arbitration & $\begin{array}{c}\text { Settle- } \\
\text { ment }\end{array}$ & & $\begin{array}{c}\text { Settlement } \\
\text { Conference }\end{array}$ & $\begin{array}{c}\text { Settle- } \\
\text { ment }\end{array}$ \\
\hline Mean & 3.70 & 3.42 & & 3.57 & 3.56 & & 3.54 & 3.75 \\
S.D. & 1.48 & 1.26 & & 1.44 & 1.50 & & 1.38 & 1.08 \\
$N$ & 96 & 19 & & 46 & 18 & & 52 & 32 \\
\hline
\end{tabular}

Question 2. "How much could you trust him/her to make decisions that were in your best interest-"

Response options: "A lot," "Some," "Not much." (Scale values = 1-4)

\begin{tabular}{lcccccccc}
\hline & \multicolumn{2}{c}{ Fairfax } & & \multicolumn{2}{c}{ Bucks } & & \multicolumn{2}{c}{ Prince Georges } \\
\cline { 2 - 3 } & Trial & $\begin{array}{c}\text { Settle- } \\
\text { ment }\end{array}$ & & Arbitration & $\begin{array}{c}\text { Settle- } \\
\text { ment }\end{array}$ & & $\begin{array}{c}\text { Settlement } \\
\text { Conference }\end{array}$ & $\begin{array}{c}\text { Settle- } \\
\text { ment }\end{array}$ \\
\hline Mean & 3.36 & 2.90 & & 3.28 & 3.12 & & 3.43 & 3.32 \\
S.D. & 1.09 & 1.26 & & 1.09 & 1.32 & & 1.00 & 0.98 \\
$N$ & 96 & 21 & & 44 & 17 & & 51 & 28 \\
\hline
\end{tabular}

PARTICIPATED IN PROCESS. "Thinking back over the whole experience, how much would you say you participated in the process of disposing of your case?"

Response options: "A lot," "Some," "A little," "Not much." (Scale values $=1-4)$ 


\begin{tabular}{|c|c|c|c|c|c|c|}
\hline & \multicolumn{2}{|c|}{ Fairfax } & \multicolumn{2}{|c|}{ Bucks } & \multicolumn{2}{|c|}{ Prince Georges } \\
\hline & Trial & $\begin{array}{c}\text { Settle- } \\
\text { ment }\end{array}$ & Arbitration & $\begin{array}{c}\text { Settle- } \\
\text { ment }\end{array}$ & $\begin{array}{l}\text { Settlement } \\
\text { Conference }\end{array}$ & $\begin{array}{c}\text { Settle- } \\
\text { ment }\end{array}$ \\
\hline $\begin{array}{l}\text { Mean } \\
\text { S.D. } \\
N\end{array}$ & $\begin{array}{l}2.86 \\
1.08 \\
98\end{array}$ & $\begin{array}{l}2.08 \\
1.14 \\
24\end{array}$ & $\begin{array}{l}2.40 \\
1.14 \\
50\end{array}$ & $\begin{array}{c}2.14 \\
1.17 \\
22\end{array}$ & $\begin{array}{c}2.53 \\
1.19 \\
51\end{array}$ & $\begin{array}{r}2.36 \\
1.13 \\
36\end{array}$ \\
\hline
\end{tabular}

PROCEDURE DIGNIFIED. "Which word best describes your (hearing/settlement conference/trial/experience [settlement])?" Response options: "Dignified," "Undignified."

\begin{tabular}{|c|c|c|c|c|c|c|}
\hline & \multicolumn{2}{|c|}{ Fairfax } & \multicolumn{2}{|c|}{ Bucks } & \multicolumn{2}{|c|}{ Prince Georges } \\
\hline & Trial & $\begin{array}{c}\text { Settle- } \\
\text { ment }\end{array}$ & Arbitration & $\begin{array}{c}\text { Settle- } \\
\text { ment }\end{array}$ & $\begin{array}{l}\text { Settlement } \\
\text { Conference }\end{array}$ & $\begin{array}{c}\text { Settle- } \\
\text { ment }\end{array}$ \\
\hline $\begin{array}{l}\text { Percent } \\
\text { dignified } \\
\text { S.D. }\end{array}$ & $89 \%$ & $57 \%$ & $86 \%$ & $67 \%$ & $73 \%$ & $81 \%$ \\
\hline $\boldsymbol{N}$ & 89 & 23 & 42 & 21 & 45 & 36 \\
\hline
\end{tabular}

COMFORTABLE WITH PROCEDURE. "Which word best describes your (hearing/settlement conference/trial/experience [settlement]?"

Response options: "Comfortable," "Uncomfortable."

\begin{tabular}{|c|c|c|c|c|c|c|}
\hline & \multicolumn{2}{|c|}{ Fairfax } & \multicolumn{2}{|c|}{ Bucks } & \multicolumn{2}{|c|}{ Prince Georges } \\
\hline & Trial & $\begin{array}{c}\text { Settle- } \\
\text { ment }\end{array}$ & Arbitration & $\begin{array}{c}\text { Settle- } \\
\text { ment }\end{array}$ & $\begin{array}{l}\text { Settlement } \\
\text { Conference }\end{array}$ & $\begin{array}{c}\text { Settle- } \\
\text { ment }\end{array}$ \\
\hline $\begin{array}{l}\text { Percent } \\
\text { comfortable } \\
N\end{array}$ & $\begin{array}{l}49 \% \\
89\end{array}$ & $\begin{array}{l}44 \% \\
23\end{array}$ & $\begin{array}{l}57 \% \\
42\end{array}$ & $\begin{array}{l}55 \% \\
22\end{array}$ & $\begin{array}{l}48 \% \\
48\end{array}$ & $\begin{array}{l}66 \% \\
35\end{array}$ \\
\hline
\end{tabular}

UNDERSTOOD PROCEDURE. "While your case was proceeding, how well did you feel you understood what was going on?"

Response options: "A lot," "Some," "A little," "Not at all." (Scale values $=1-4$ )

\begin{tabular}{|c|c|c|c|c|c|c|}
\hline & \multicolumn{2}{|c|}{ Fairfax } & \multicolumn{2}{|c|}{ Bucks } & \multicolumn{2}{|c|}{ Prince Georges } \\
\hline & Trial & $\begin{array}{c}\text { Settle- } \\
\text { ment }\end{array}$ & Arbitration & $\begin{array}{c}\text { Settle- } \\
\text { ment }\end{array}$ & $\begin{array}{l}\text { Settlement } \\
\text { Conference }\end{array}$ & $\begin{array}{c}\text { Settle- } \\
\text { ment }\end{array}$ \\
\hline $\begin{array}{l}\text { Mean } \\
\text { S.D. } \\
N\end{array}$ & $\begin{array}{c}3.70 \\
0.63 \\
97\end{array}$ & $\begin{array}{r}3.25 \\
0.94 \\
24\end{array}$ & $\begin{array}{c}3.45 \\
0.76 \\
51\end{array}$ & $\begin{array}{c}3.23 \\
1.11 \\
22\end{array}$ & $\begin{array}{c}3.22 \\
0.90 \\
51\end{array}$ & $\begin{array}{l}3.09 \\
1.17 \\
35\end{array}$ \\
\hline
\end{tabular}

\section{PROCEDURE CAREFUL}

Question 1. "Which word best describes your (hearing/settlement conference/trial/experience [settlement])?"

Response options: "Careful," "Casual." 


\begin{tabular}{|c|c|c|c|c|c|c|}
\hline & \multicolumn{2}{|c|}{ Fairfax } & \multicolumn{2}{|c|}{ Bucks } & \multicolumn{2}{|c|}{ Prince Georges } \\
\hline & Trial & $\begin{array}{c}\text { Settle- } \\
\text { ment }\end{array}$ & Arbitration & $\begin{array}{c}\text { Settle- } \\
\text { ment }\end{array}$ & $\begin{array}{l}\text { Settlement } \\
\text { Conference }\end{array}$ & $\begin{array}{c}\text { Settle- } \\
\text { ment }\end{array}$ \\
\hline $\begin{array}{l}\text { Percent } \\
\text { careful } \\
N\end{array}$ & $\begin{array}{l}77 \% \\
88\end{array}$ & $\begin{array}{l}44 \% \\
23\end{array}$ & $\begin{array}{l}45 \% \\
42\end{array}$ & $\begin{array}{l}41 \% \\
22\end{array}$ & $\begin{array}{l}52 \% \\
48\end{array}$ & $\begin{array}{l}\mathbf{7 1 \%} \\
35\end{array}$ \\
\hline
\end{tabular}

Question 2. [Same question as above, but different response options.]

Response options: "Superficial," "Thorough."

\begin{tabular}{|c|c|c|c|c|c|c|}
\hline & \multicolumn{2}{|c|}{ Fairfax } & \multicolumn{2}{|c|}{ Bucks } & \multicolumn{2}{|c|}{ Prince Georges } \\
\hline & Trial & $\begin{array}{c}\text { Settle- } \\
\text { ment }\end{array}$ & Arbitration & $\begin{array}{c}\text { Settle- } \\
\text { ment }\end{array}$ & $\begin{array}{l}\text { Settlement } \\
\text { Conference }\end{array}$ & $\begin{array}{c}\text { Settle- } \\
\text { ment }\end{array}$ \\
\hline $\begin{array}{l}\text { Percent } \\
\text { superficial } \\
N\end{array}$ & $\begin{array}{l}87 \% \\
88\end{array}$ & $\begin{array}{l}65 \% \\
23\end{array}$ & $\begin{array}{l}91 \% \\
42\end{array}$ & $\begin{array}{l}72 \% \\
22\end{array}$ & $\begin{array}{l}88 \% \\
48\end{array}$ & $\begin{array}{l}64 \% \\
35\end{array}$ \\
\hline
\end{tabular}

